\title{
ENERGETIC, ENVIRONMENTAL AND ECONOMIC PERFORMANCE OF ELECTRIC VEHICLES: EXPERIMENTAL EVALUATION
}

\author{
Tariq MUNEER \\ Transport Research Institute, Edinburgh Napier University, Merchiston Campus, Edinburgh, \\ EH10 5DT, UK
}

Ross Milligan,

Edinburgh College, Bankhead Avenue, Edinburgh EH11 4DE, UK

Ian Smith,

Transport Research Institute, Edinburgh Napier University, Merchiston Campus, Edinburgh, EH10 5DT, UK

\begin{abstract}
Aisling Doyle,
Transport Research Institute, Edinburgh Napier University, Merchiston Campus, Edinburgh, EH10 5DT, UK
\end{abstract}

\section{Miguel Pozuelo}

Transport Research Institute, Edinburgh Napier University, Merchiston Campus, Edinburgh, EH10 5DT, UK

\section{Matjaz Knez ${ }^{1}$,}

University of Maribor, Faculty of Logistics, Mariborska cesta 7, 3000 Celje, Slovenia, E-mail: matjaz.knez@fl.uni-mb.si, Tel.: +38634285336

\begin{abstract}
Fuelled by a rapidly rising human global population, an increasing demand for freedom to travel and the affordability made possible by modern manufacturing there has been an exponential rise in the number of automobiles - in the year 2013 there were in excess of a billion automobiles in use! Three factors that are of serious concern are the consequential energetic, environmental and economic impacts. One solution that is being seen by a number of national governments is the advent (or rather re-introduction) of electric vehicles (EVs). However, one of the key factors that will need to be explored will be the source of the required electricity for the EVs that will define the level of their sustainability. In this article an experimental evaluation of an electric vehicle has been undertaken. The Renault Zoe e-car has been used for this task with the 'car chasing' technique employed to measure the driving cycle. The speed and energy use were recorded for the vehicle that was driven along the principal arteries of the City of Edinburgh, Scotland. In a separate activity vehicle driving tests were also undertaken in one
\end{abstract}

${ }^{1}$ Corresponding author. 
town in Slovenia (Celje). In both places urban and suburban routes were covered for different times of the day. Results are presented to quantify the energetic, environmental and economic performance indices for the driven vehicle. A discussion is also provided on the potential for reduction of carbon emissions from the transport sector by provision of environmentally-friendly means of generating electricity.

Keywords: sustainable transport, electric vehicles, carbon emissions

\section{INTRODUCTION}

The United Nations estimate that $60 \%$ of the world's population will be living in urban areas by 2030 . Cities account for $2 \%$ of the world's area and for $75 \%$ of the world's energy consumption. For over a century, the automobile has offered affordable freedom of movement within urban areas. According to the Wards Auto (2014), global registrations jumped from 980 million units in 2009 to 1.015 billion in 2010.The world population exceeded 7 billion on March 12, 2012 and every seventh person now owns a vehicle which in all likelihood is powered by an internal combustion engine (ICE). Worldwide, 18 million barrels of oil are consumed each day by the automobile sector. Annually, the vehicles emit 2.7 billion tonnes of $\mathrm{CO}_{2}$ (IEA, 2012).

From a climate change perspective the release of such large amounts of $\mathrm{CO}_{2}$ will need to be examined. In this respect the possible link between human population growth, car ownership increase, global $\mathrm{CO}_{2}$ concentration and temperature is presently explored. Furthermore, a critical review of the present road transport relating to energy demand for UK and Slovenia is carried out. A closer examination of the road transport energy needs was undertaken through experimental work in Edinburgh (Scotland) and Celje (Slovenia). A software program has been used to ascertain the savings in fossil fuel that may be achieved by using electric vehicles.

\section{CLIMATE CHANGE AND THE POTENTIAL CONTRIBUTION OF AUTOMOBILE: BRIEF OVERVIEW}

\subsection{General considerations}

The issue of climate change has been discussed within the scientific community as well as in popular media to such an extent that it has become $a$ priori to almost all discussions related to sustainable use of energy. In this section material is presented with a view to chronologically relate some of the causes and effects. In this respect Figures 1-7 may be viewed in conjunction.

Figure 1 shows the anomalous behaviour of global temperature change since the latter part of the industrial revolution when significant carbon loading of the planet had ensued, while Figure 2 shows an exponential rise of atmospheric $\mathrm{CO}_{2}$ concentration. That behaviour may then be, at least loosely, traced to Figures 3-7 which show a combined effect of a sharp rise of human population, rise in the number of automobiles on the road and increased use of fossil fuels that are consumed to drive the vehicles. Note that for developed economies of Western Europe the transport related emissions are beginning to stabilize, as shown in Figure 6 but for the world as a whole a rapidly rising profile is evident. Furthermore, as shown in Figure 7 the present proportion of $23 \%$ share of $\mathrm{CO}_{2}$ emissions for global transport is set to rise. 
Figure 6 may also be compared with Figure 8 which shows that much greater emission efficiency has been achieved by tightening EU legislation, i.e. although there is an increase in energy use, the greenhouse gas emissions have a decreasing profile due to the trend shown in Figure 9. There has also been a heavy thermal loading of sea waters as shown in Figure 10 which ought to be seen in conjunction with Figure 11 which demonstrates a sharp decline of solubility of $\mathrm{CO}_{2}$ in sea water. Note that the annual average temperature of North Atlantic Sea which huddles the major economies is 6 Celsius during winter months and 17 Celsius in summer (MUMM, 2014). The seas of planet Earth hold 40 atmospheres of $\mathrm{CO}_{2}$ by mass. Therefore, any slight sea temperature elevation would release an abundance of $\mathrm{CO}_{2}$. This argument is particularly relevant to power plants including those that are nuclear-fuelled which would typically dump twice the amount of their useful energy output to their cooling systems. To address the issue of Climate Change the European Union has set itself a challenging task of a serious overall reduction of greenhouse gas (GHG) emissions. Figure 12 shows those targets for the developed economies within the EU28 member countries.

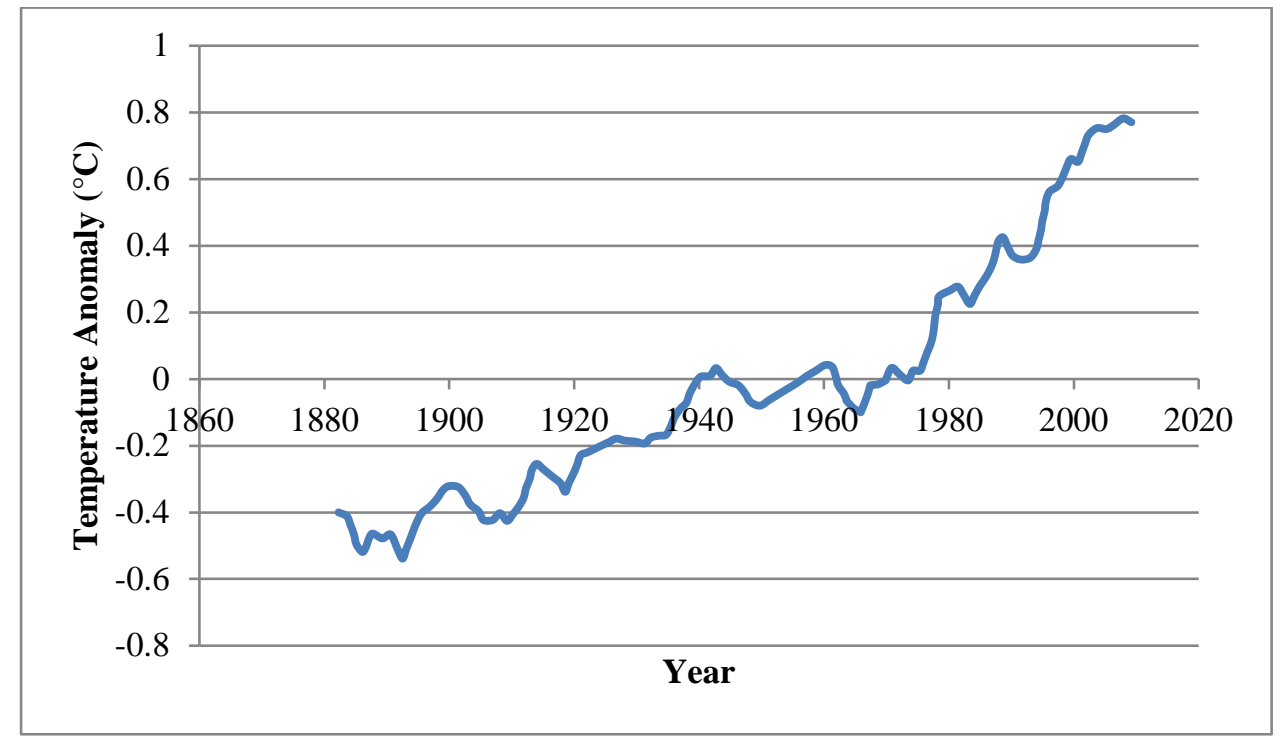

Figure 1: Chronology of Global Temperature Change (Maurice et al., 2012) 


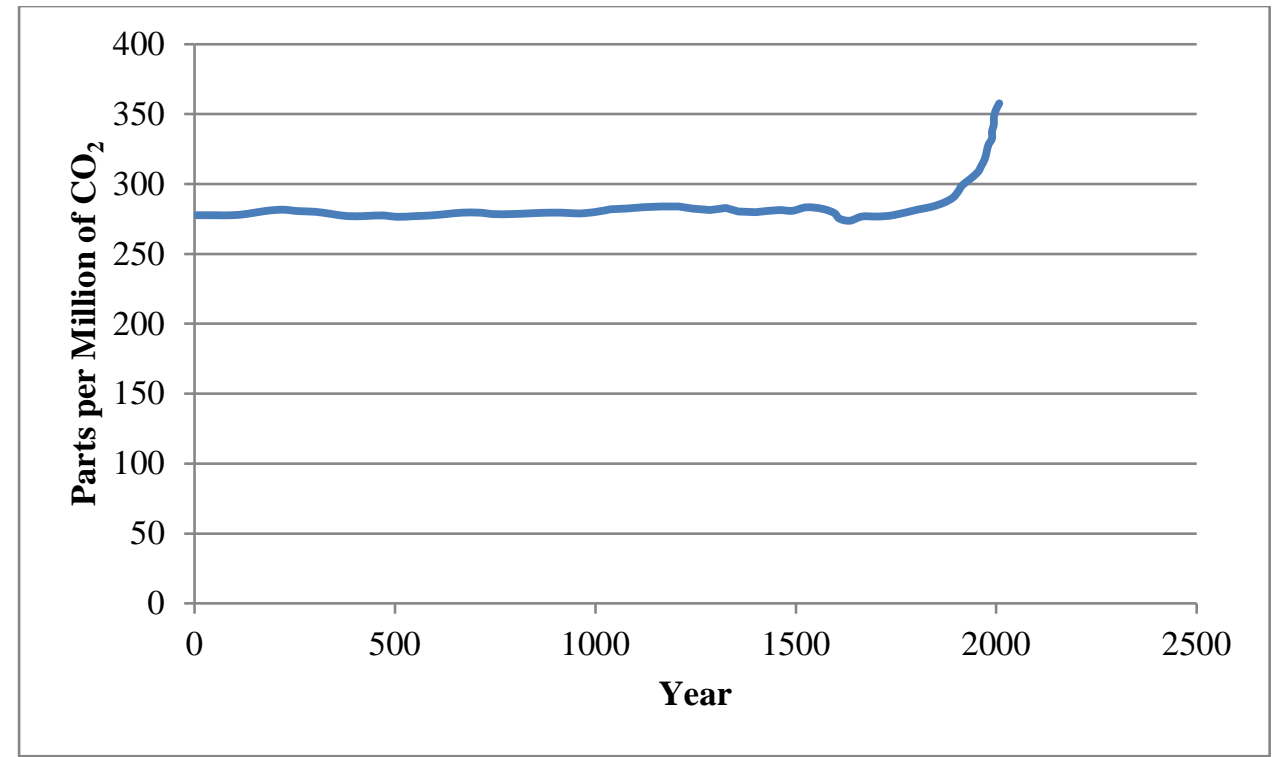

Figure 2: Chronology of Global Atmospheric $\mathrm{CO}_{2}$ Concentration (IPCC, 2007)

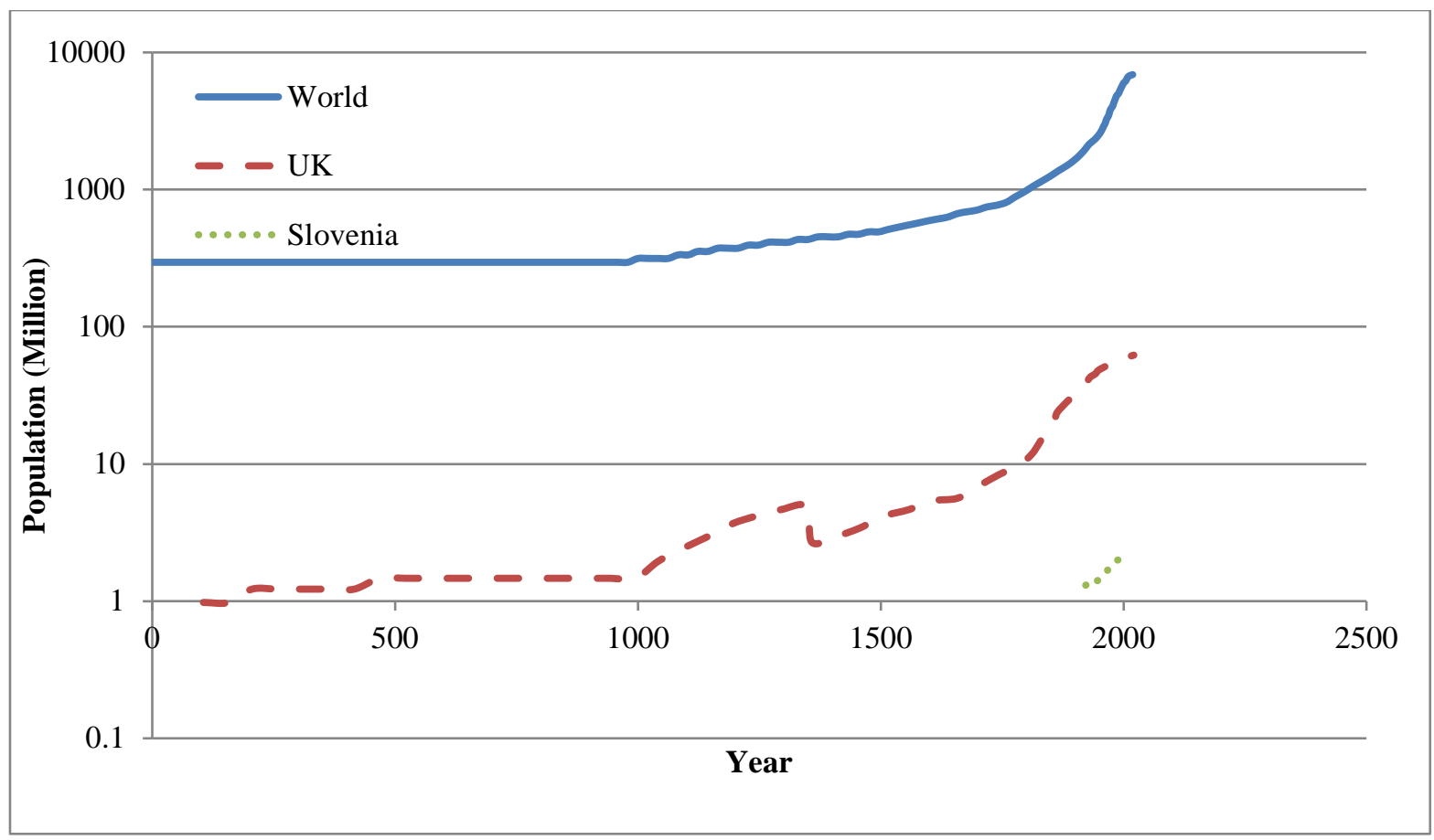

Figure 3: Human Population Increase (Emmott, 2013, SURS, 2014) 


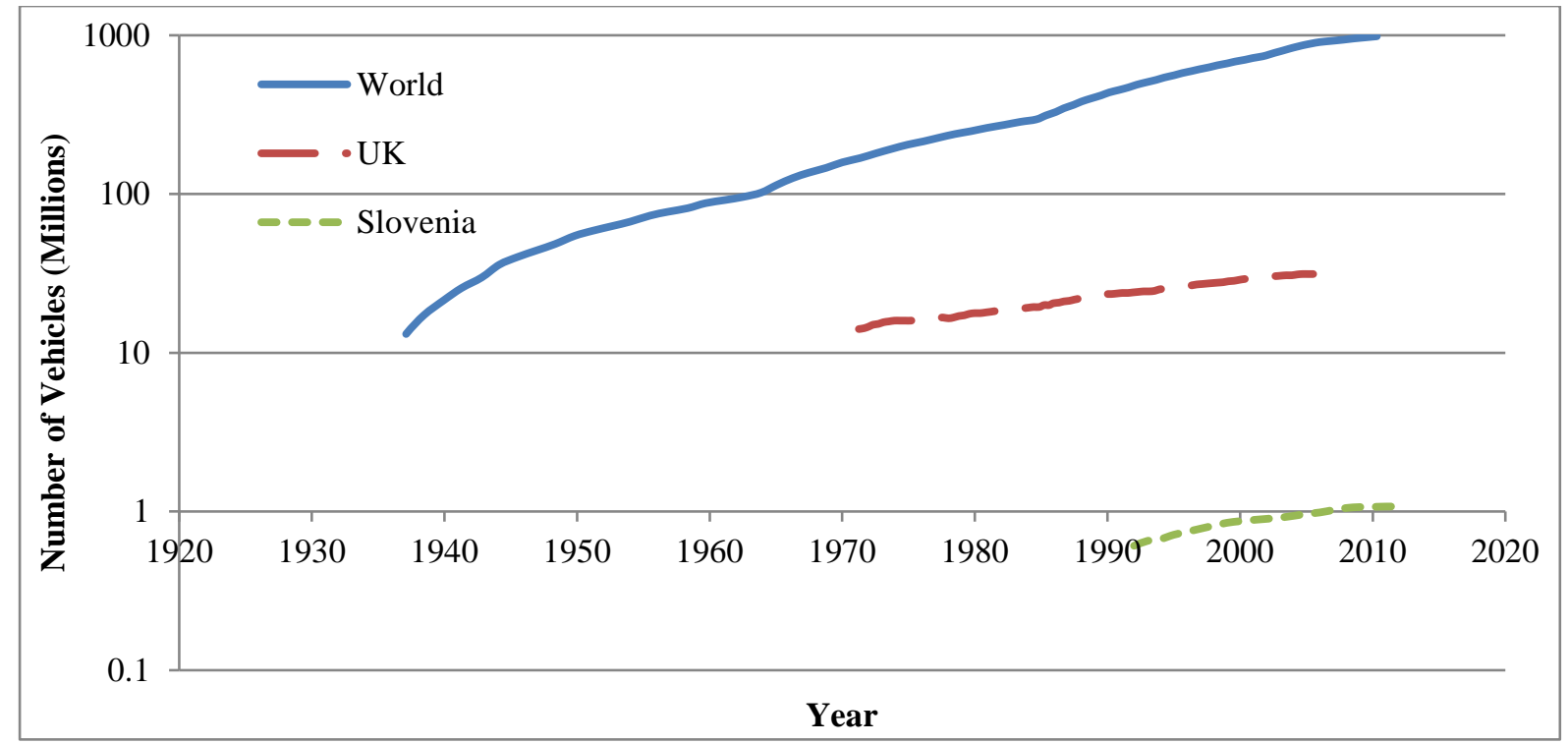

Figure 4: Chronology of number of vehicles (SURS, 2014a, Leibling, 2008, Emmott, 2013)

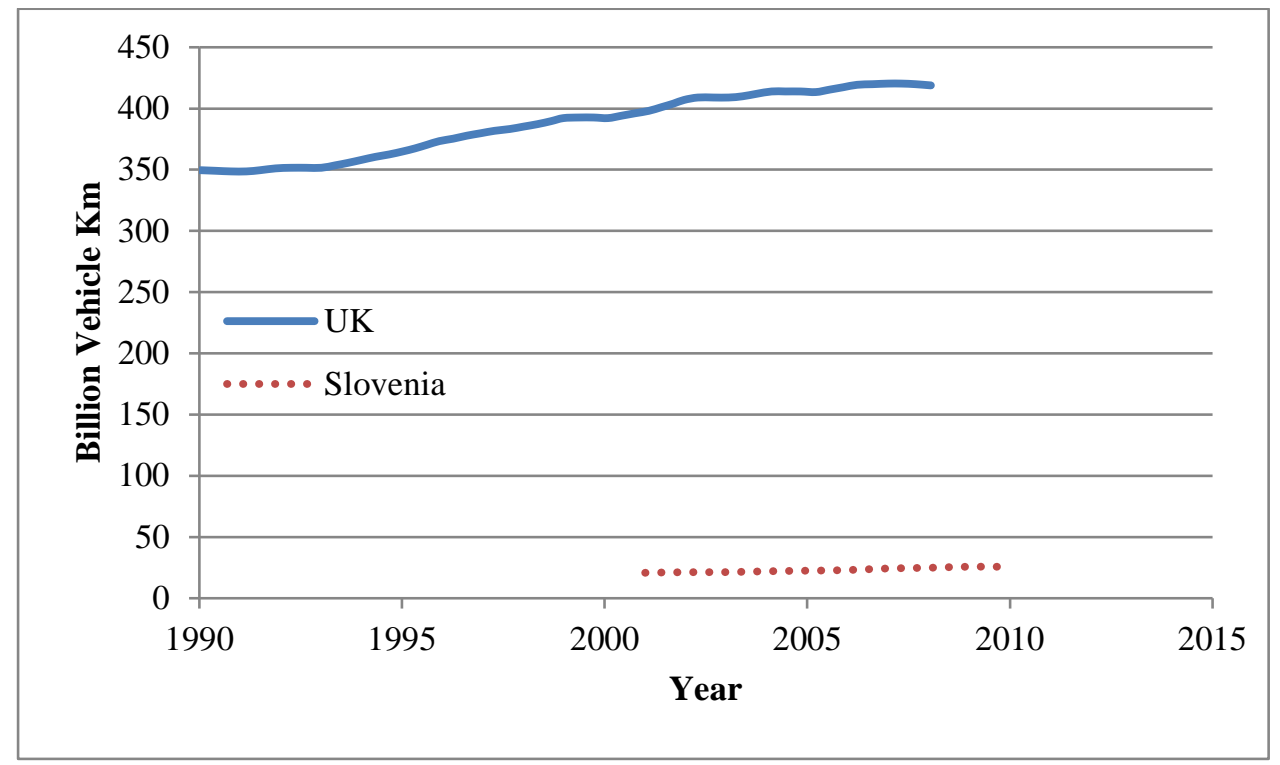

Figure 5: Total usage of Automobiles (CCC, 2010, SURS, 2014b) 


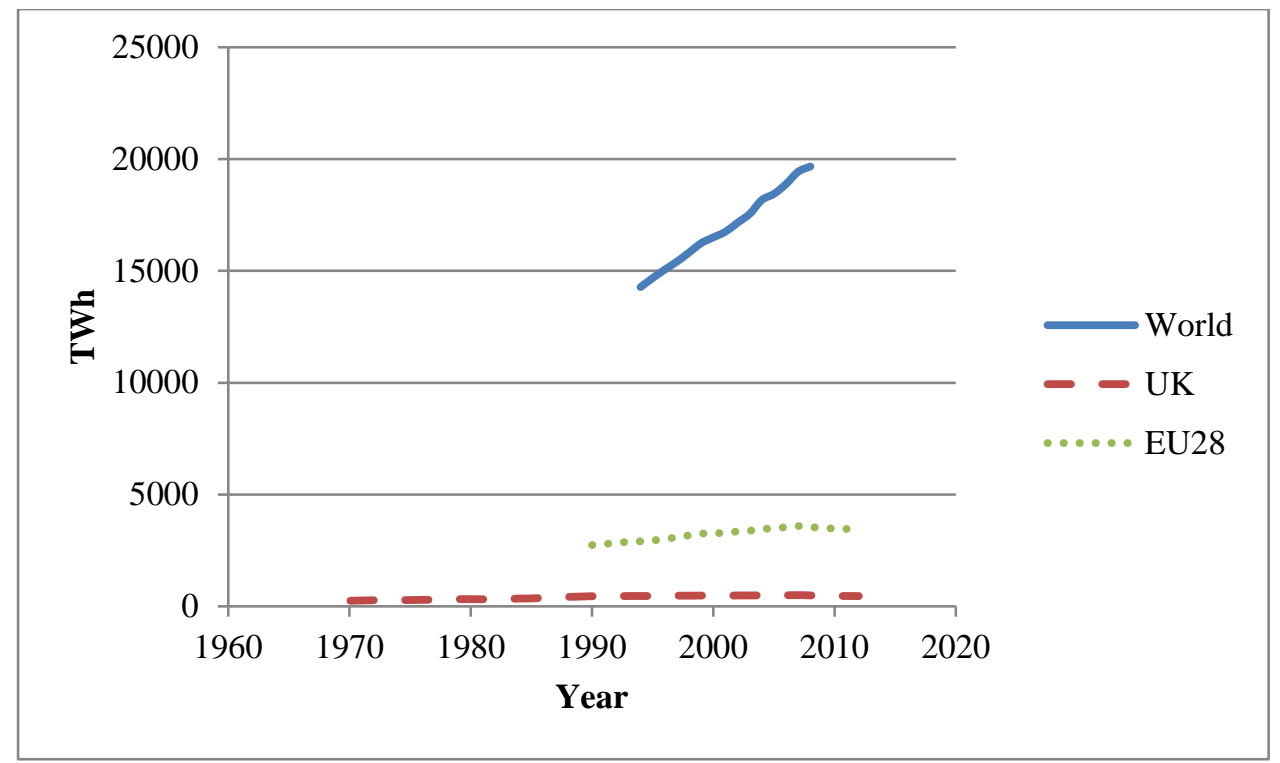

Figure 6: Chronology of Transport Related Energy Consumption (World Bank, 2014, EEA, 2014)

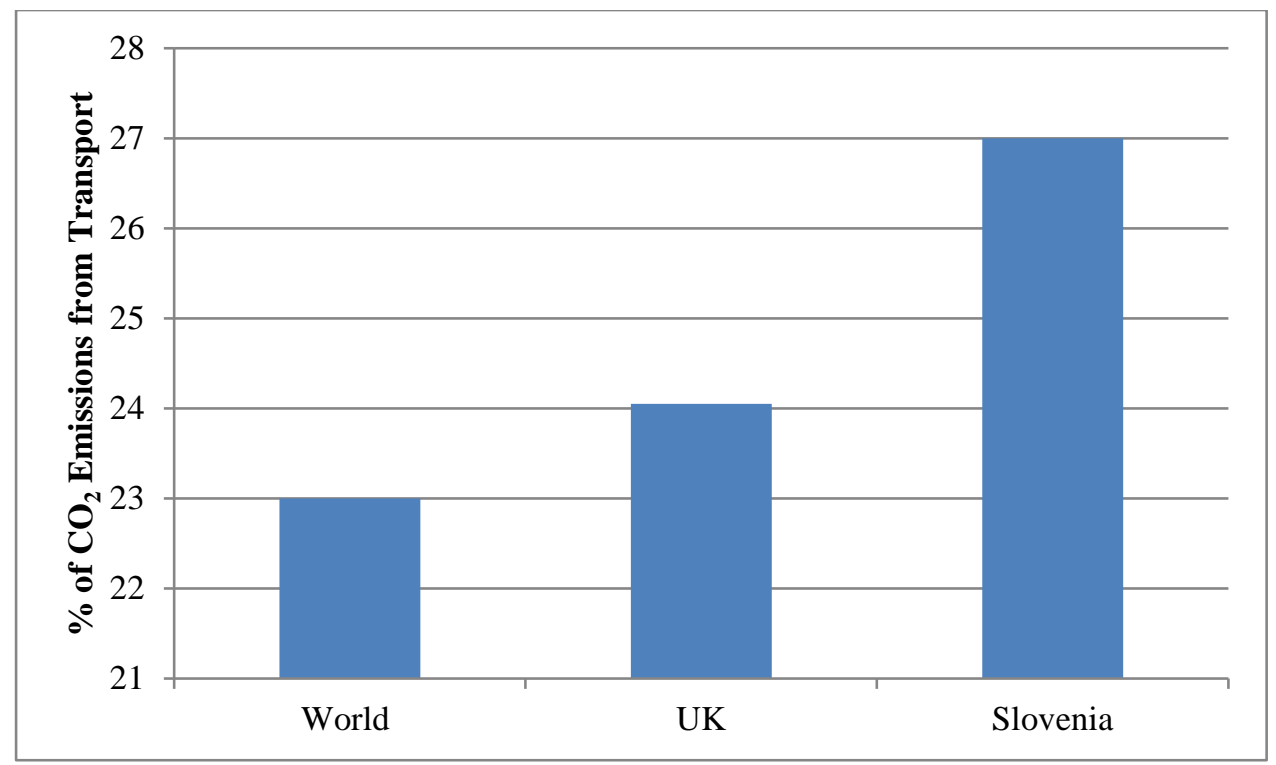

Figure 7: Per Cent of $\mathrm{CO}_{2}$ Emissions from Transport Sector 2010 (EEA, 2010, DECC, 2014, IEA, 2012) 


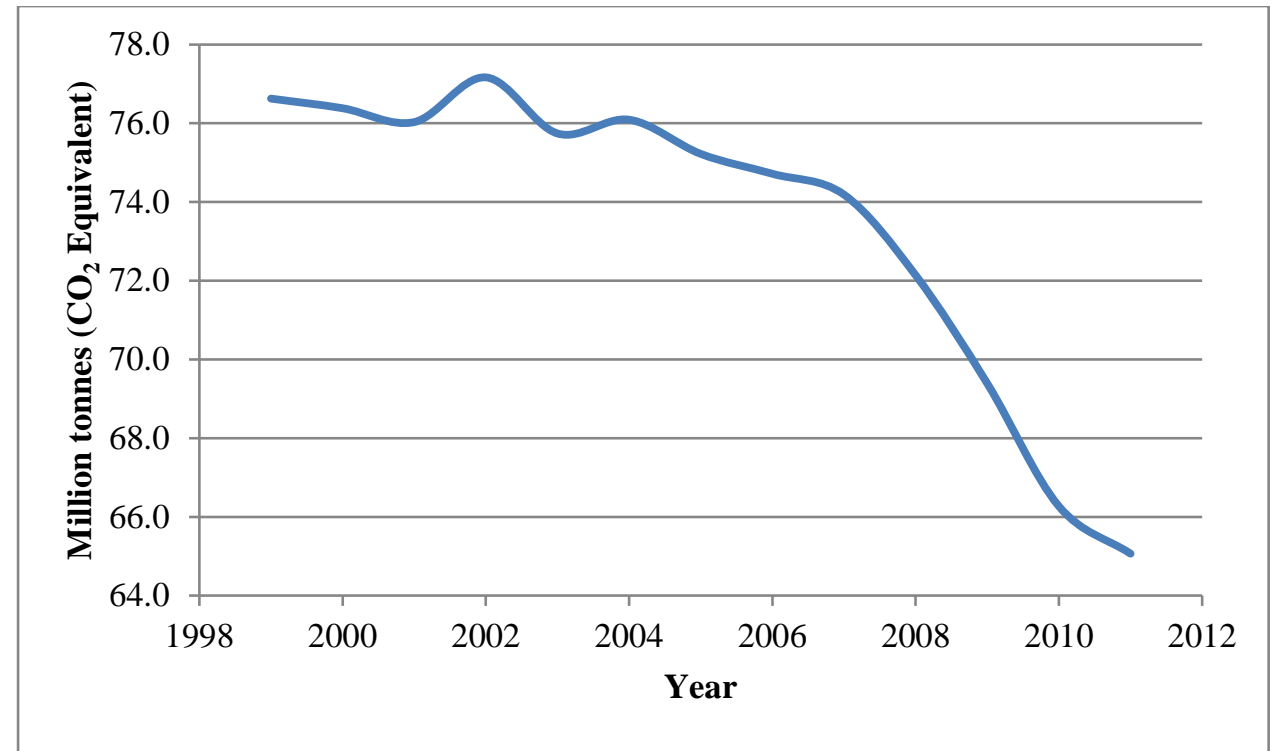

Figure 8: $\mathrm{CO}_{2}$ Emissions from Cars and Taxis in the UK (Department for Transport, 2013)

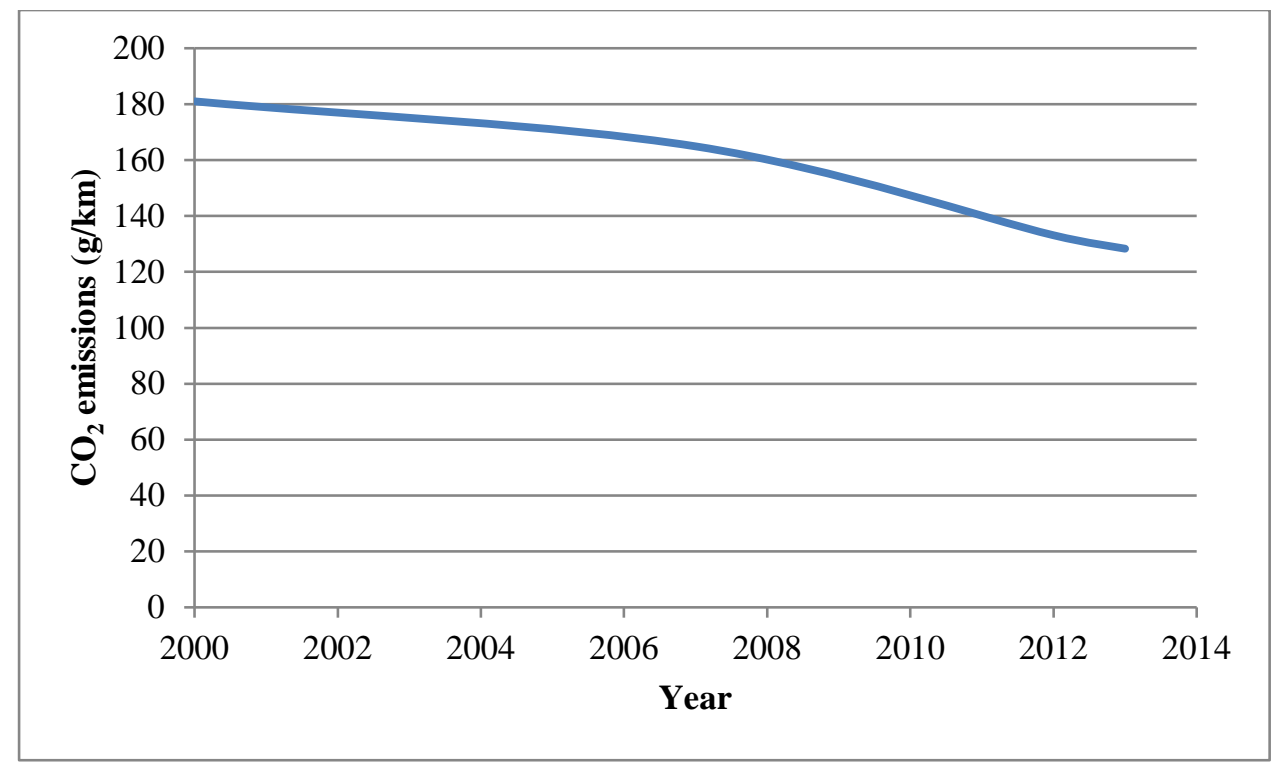

Figure 9: Average New Car $\mathrm{CO}_{2}$ Emissions (Department for Transport, 2013a) 


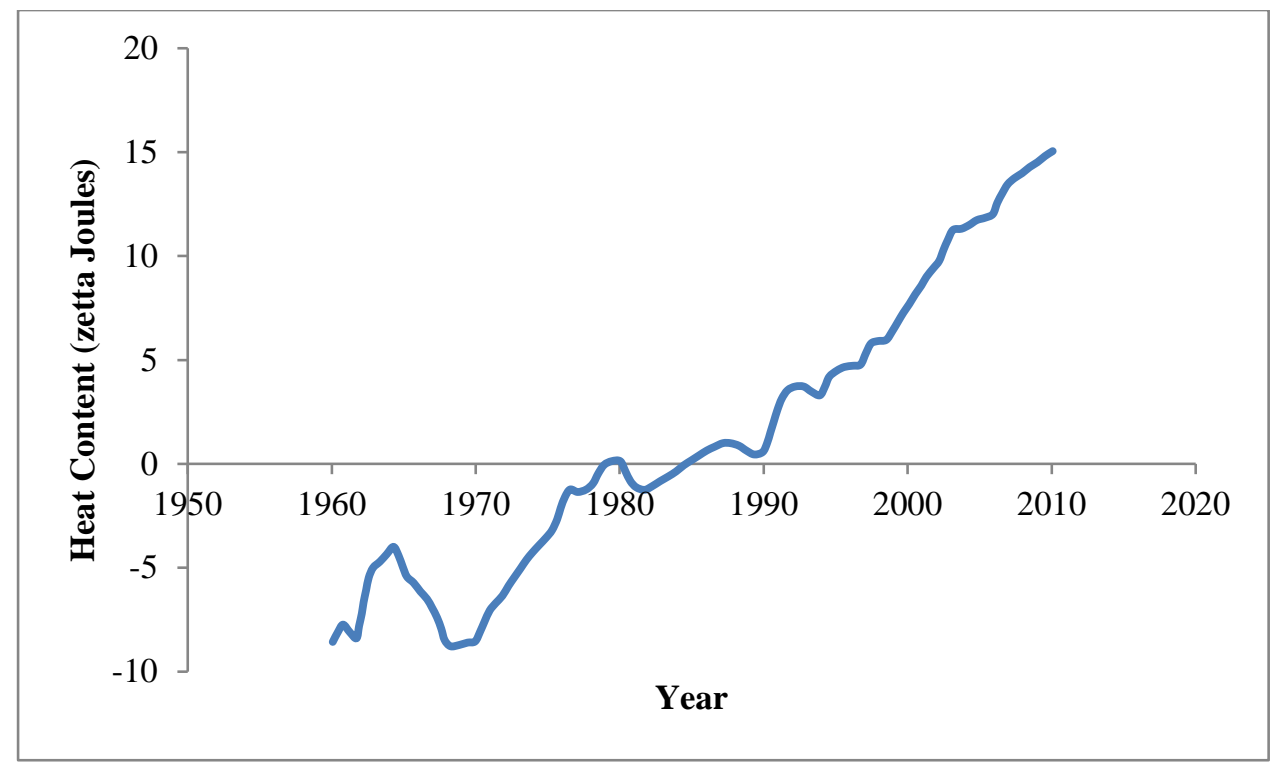

Figure 10: Thermal Loading of Sea. Note: 1 Zetta Joule $=1021$ Joules (Levitus et al., 2012)

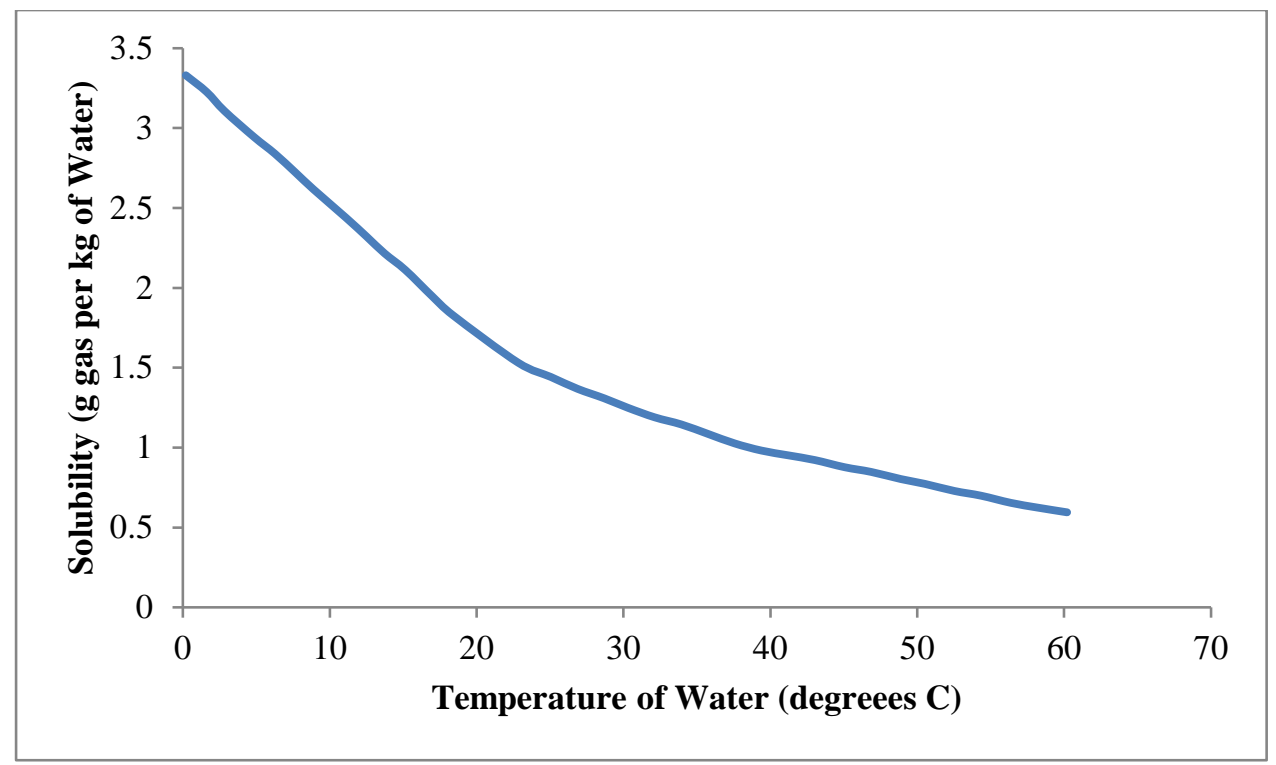

Figure 11: Solubility Plot for $\mathrm{CO}_{2}$ in water (Engineering Toolbox, 2014) 


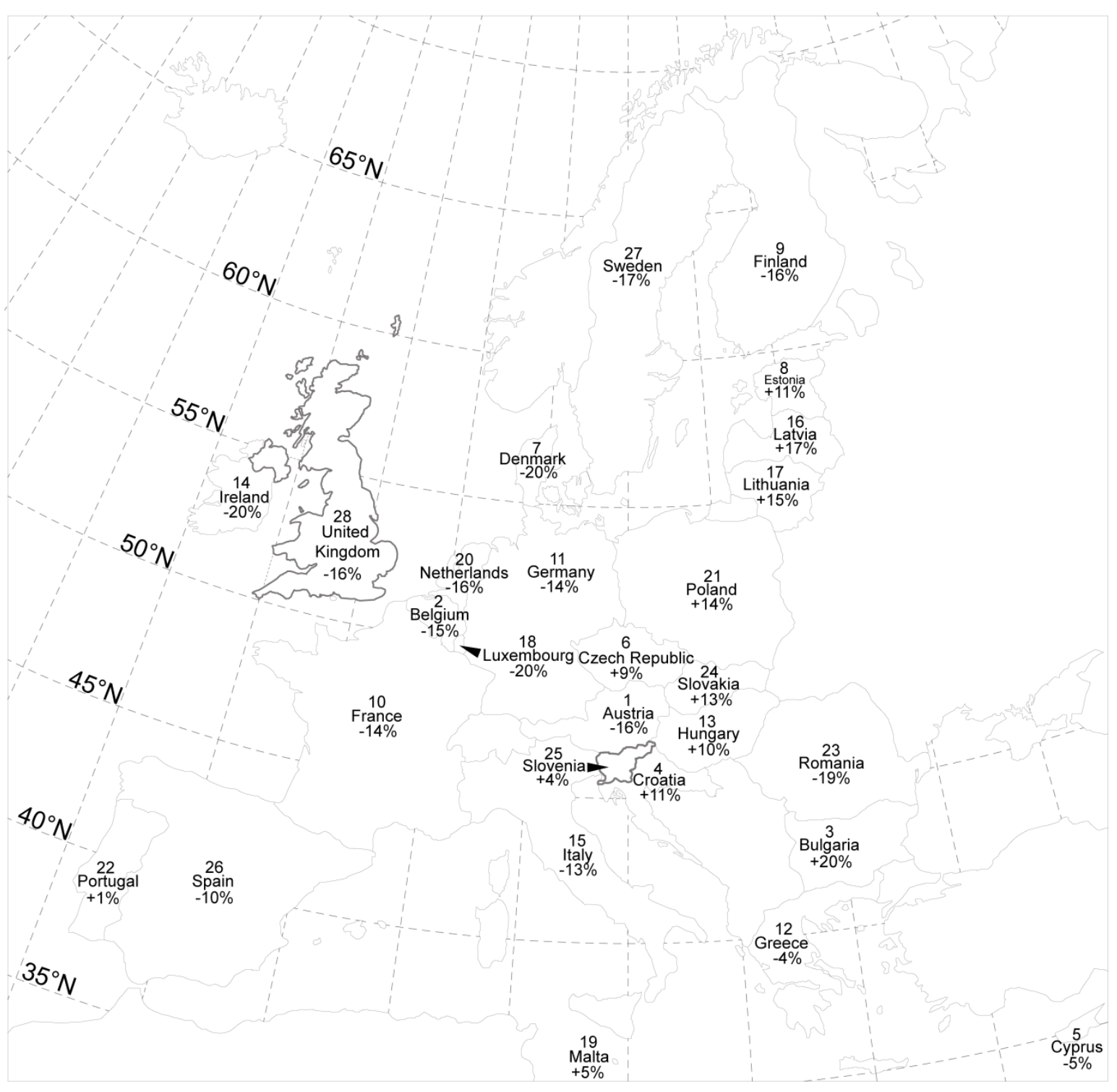

Figure 12: EU Member State GHG Emission Limits for year 2020 Compared to 2005 Levels (Holyrood Renewables, 2014)

\subsection{Impact of automobiles}

The resident population of England and Wales on 27 March 2011 was 56.1 million. The number of cars and vans available to households in England and Wales increased from 23.9 million in 2001 to 27.3 million in 2011. In 2001 there were on average 11 cars per 10 households whereas in 2011 there were 12 cars per 10 households. Scotland's population on census day 2011 was estimated to be 5,295,403. In 2011, 69 per cent of households had at least one car or van available, compared with 66 per cent of households in 2001. The total number of cars and vans available to households in Scotland in 2011 was 2.5 million, compared with 2 million in 2001 (Office for National Statistics, 2011).

Transport emissions make up just over a quarter of Scotland's total emissions, with more than two thirds of these emissions coming from road transport. For England and Wales a similar statistic is reported. Furthermore, poor air quality reduces the UK life expectancy by an average of 7-8 months and up to 50,000 people a year die prematurely because of it (Office for National Statistics, 2011). 
Figures 13-15 present further data related to automobiles. Figure 13 presents a relationship between population density and automobile ownership, the data being pooled from Scottish cities and towns. There seems to be a definite relationship between the above two parameters. Local and Central governments across the world are trying to wean people off personal transport with appropriate policies such as high car parking charges, parking permits for local residents and inducements for the use of public transport which seem to pay the dividends. For example, within the past two decades in Slovenia and Scotland the on-street car parking charges shot-up by a factor of 10! Figure 14 presents the usage pattern for automobiles. This information will be of use when we visit the problem of gradually replacing fossil-fuelled vehicles with electrically propelled units and the charging related issue. The fossil-fuelled automobile has served mankind for over a hundred years but its energy audit shown in Figure 15 indicates an efficiency of only 13\% to move the vehicle mass. Mitchell et al. (2010) have shown that in terms of overall efficiency of the useful energy contribution to transport the driver has a value of less than $1 \%$ !

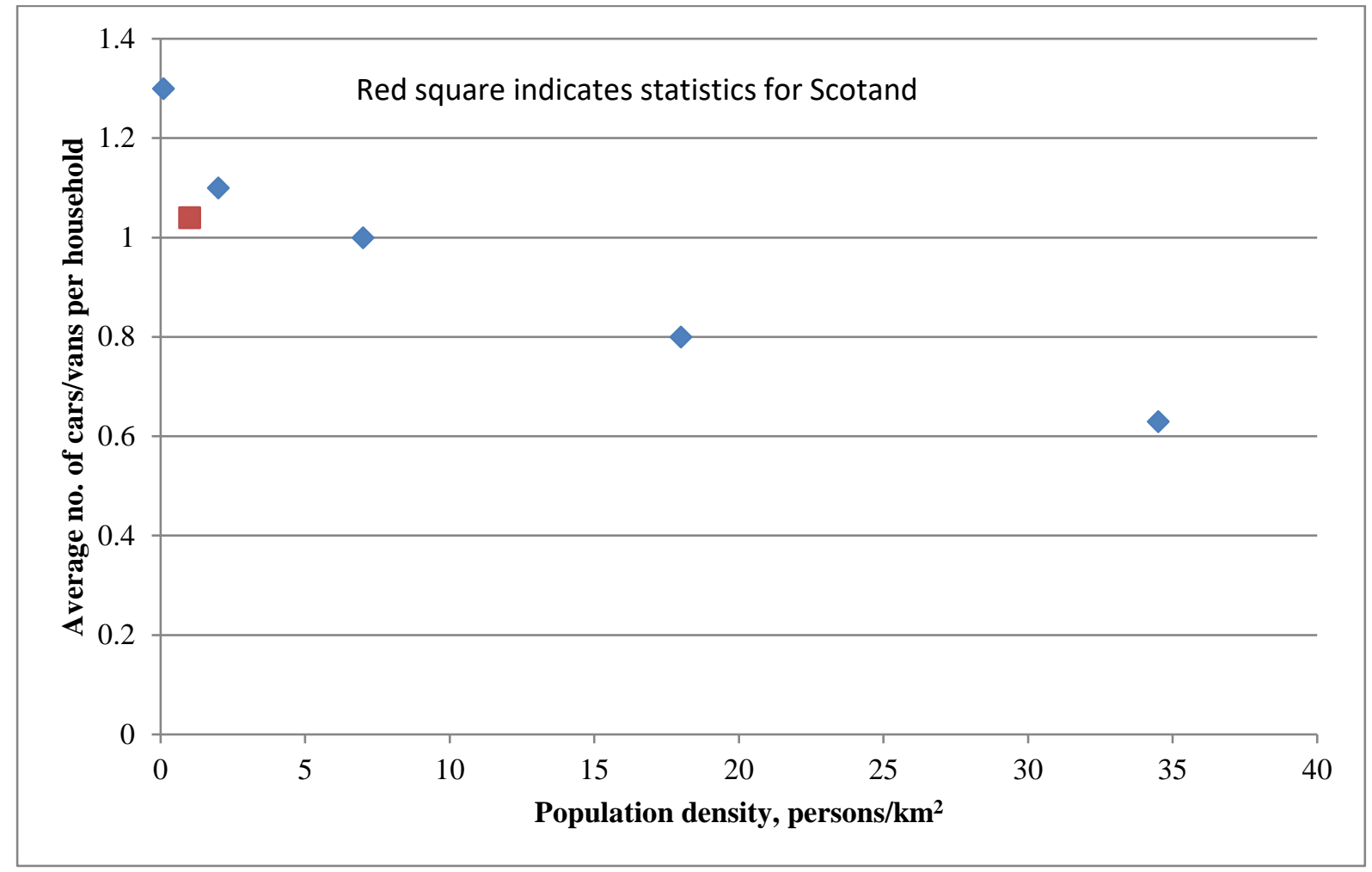

Figure 13: Link between Population Density and Vehicle Ownership (Office for National Statistics, 2011). 


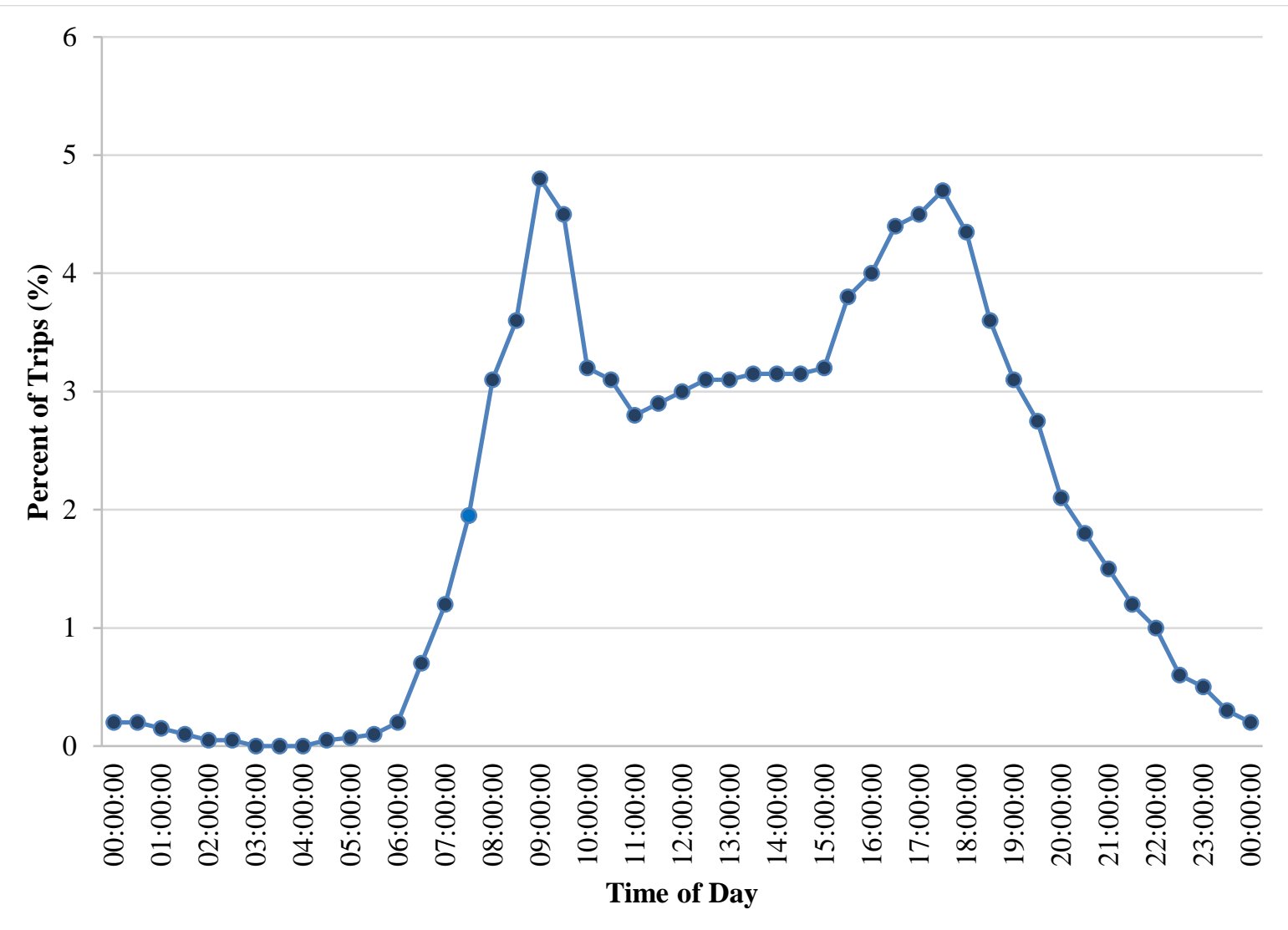

Figure 14: UK Vehicle Travel Profile in an Urban Area (Office for National Statistics, 2011).

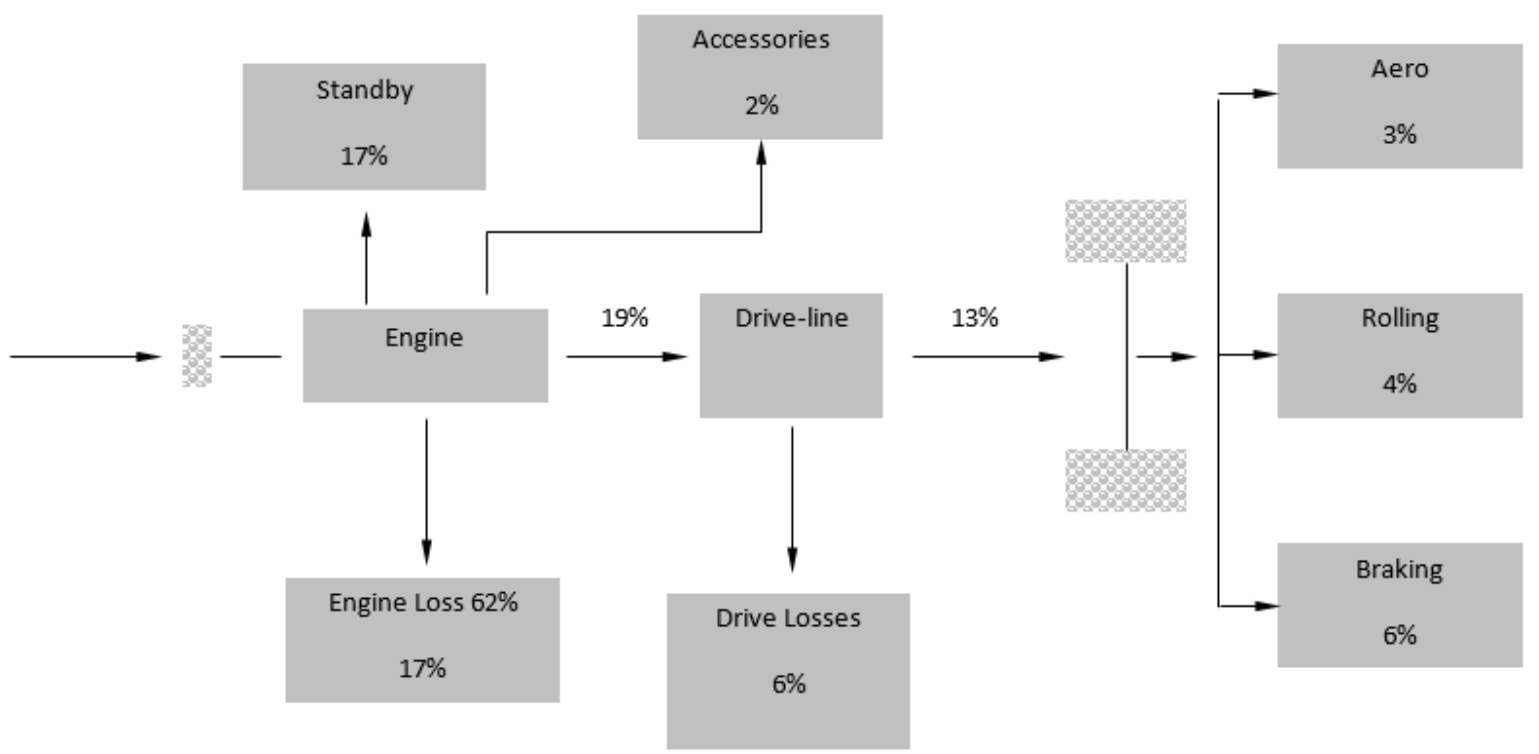

Figure 15: Energy Losses in an Automobile (Mitchell et al., 2010) 


\subsection{Electricity generation and its impact}

Data collected by IEA for the OECD countries indicates that currently $60 \%$ of the electricity is generated by burning fossil fuels. Therefore, when one compares the energetic and environmental impact of electrical propelled vehicles against the fossil-fuelled ones it is important to audit the $\mathrm{CO}_{2}$ emissions associated with electricity generation. In this respect the data presented in Figures 16-19 is relevant. Note that in the period from January 2010 until December 2012 the maximum electricity demand in UK was $44.4 \mathrm{GW}$, the latter event occurring at 17:00 on December $31^{\text {st }}$, 2012. Figure 16 presents the average 10th and 90th percentile data for UK demand. This information shall be of use in ascertaining the design of charging networks for electric vehicles across the UK (IEA, 2012).

Figure 17 presents data related to the share of fuels that contribute to electricity generation. While twothirds electrical energy generation for the world as a whole is from fossil-fuels, for Scotland that fraction drops to $40 \%$. Figure 18 presents a more detailed analysis of the latter subject and includes the relevant energy quantities. Of particular note is the considerable increase of 'Other Renewables' which is mainly the contribution of wind farms. Scotland has a very ambitious target of $100 \%$ carbon-free electricity by 2020 (The Guardian, 2010).

Figure 19 provides $\mathrm{CO}_{2}$ emission intensity data. The sharp contrast between fossil-fuel and renewable source is evident. Even with a weak solar energy resource a nine-year, Edinburgh based solar PV monitoring project has indicated emission intensity of 44 grams of $\mathrm{CO}_{2}$ (Muneer et al., 2006). With onshore wind and hydro power that figure drops to 11 and 5 grams of $\mathrm{CO}_{2}$.

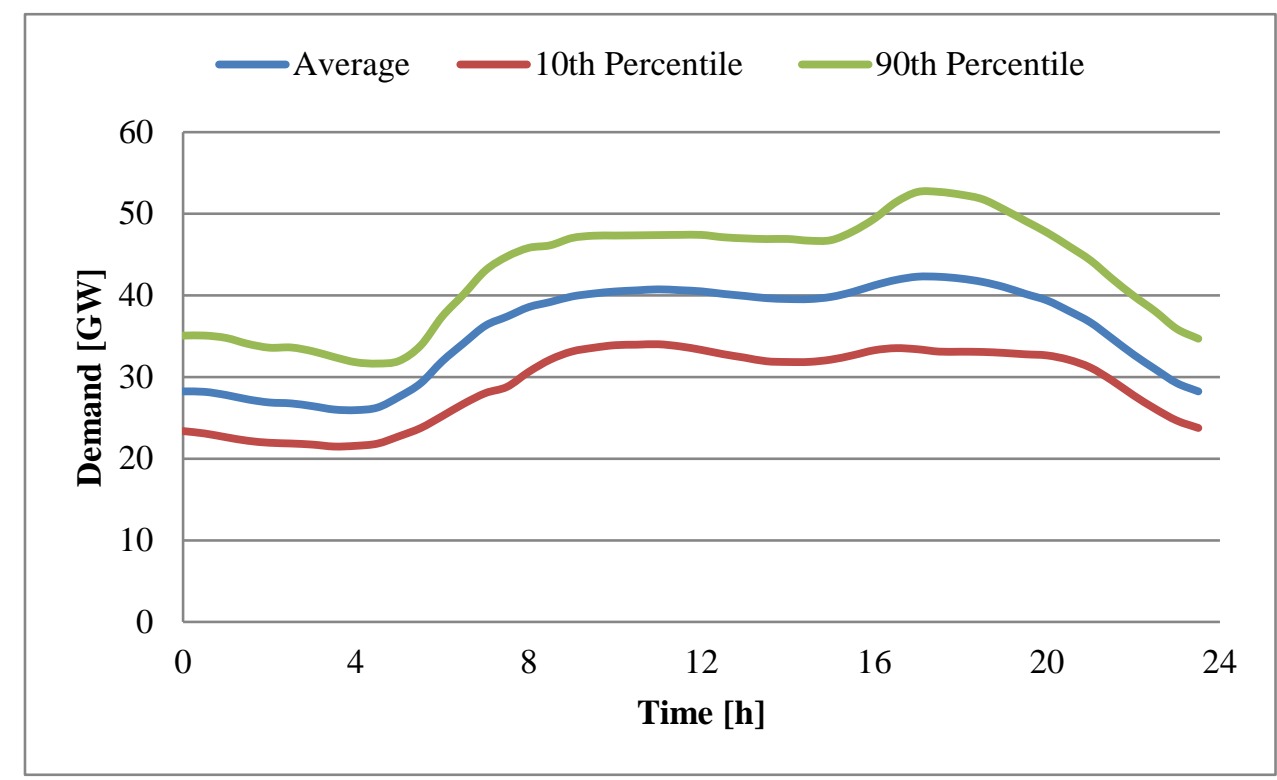

Figure 16: UK Electricity Demand Profile (National Grid, 2014) 


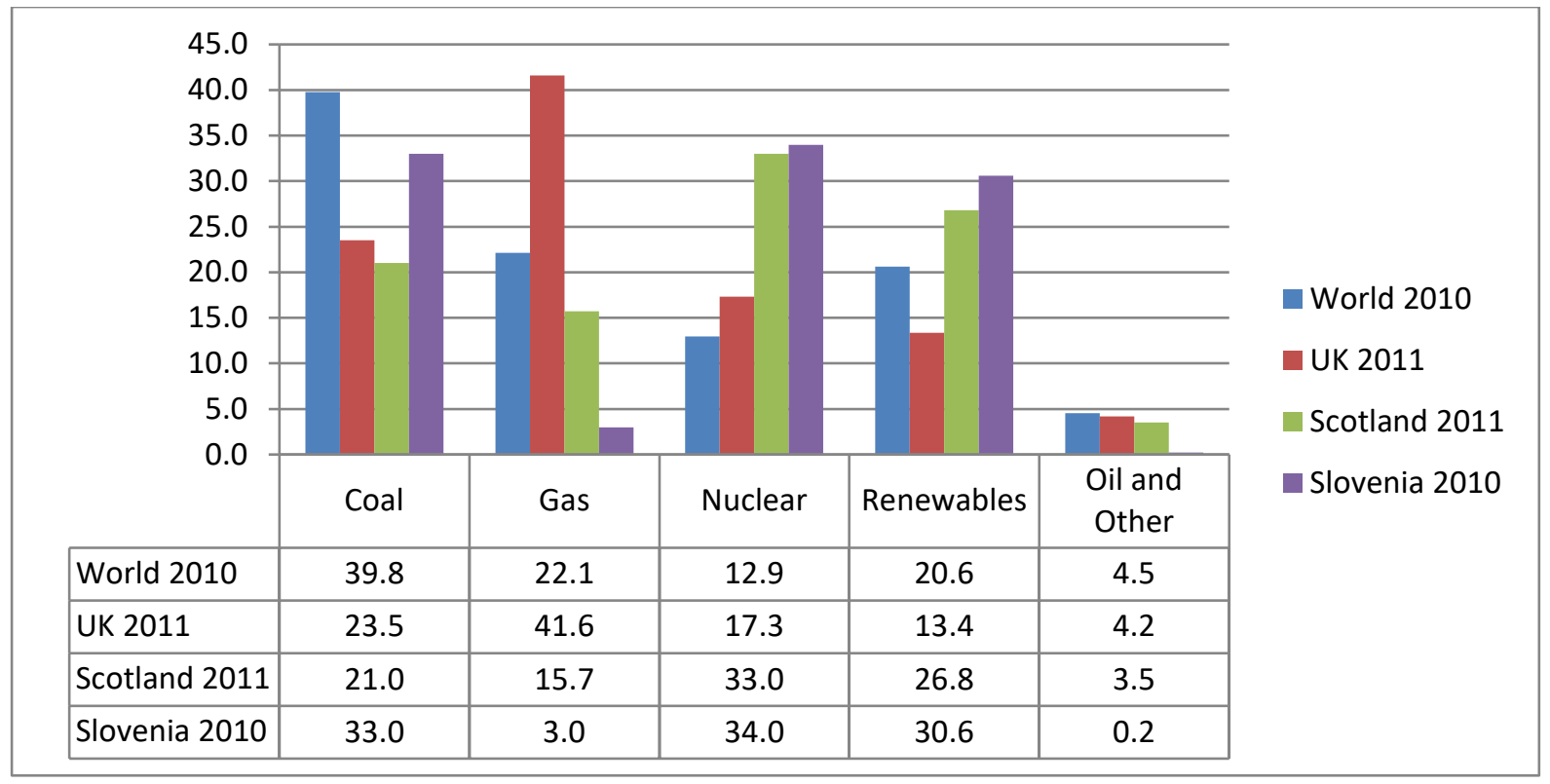

Figure 17: Percentage Share of Fuel Used for Electricity Generation (OECD, 2011, Hemingway and Michaels, 2012)

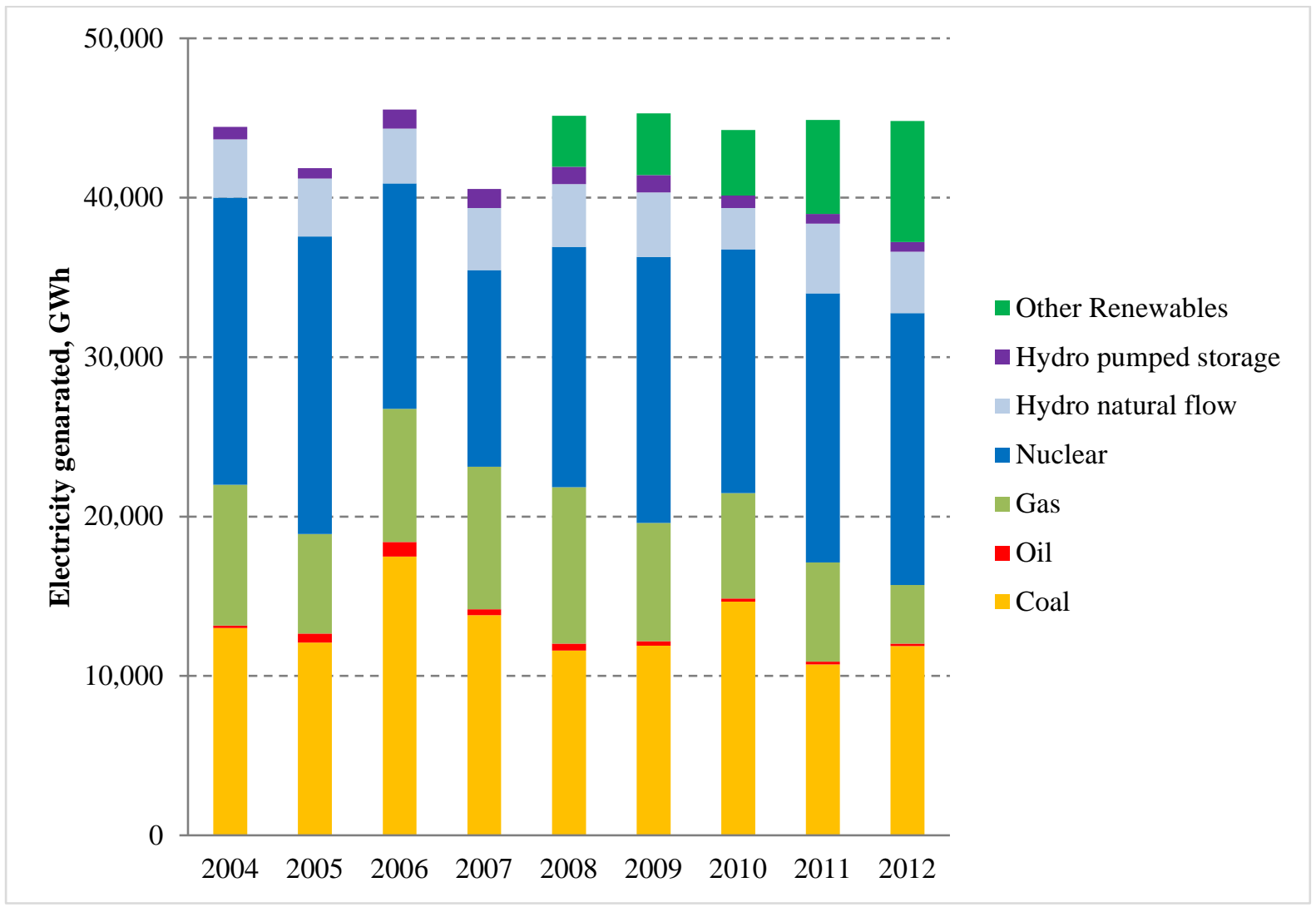

Figure 18: Electricity Generated in Scotland, by Fuel (GWh) (The Scottish Government, 2012) 


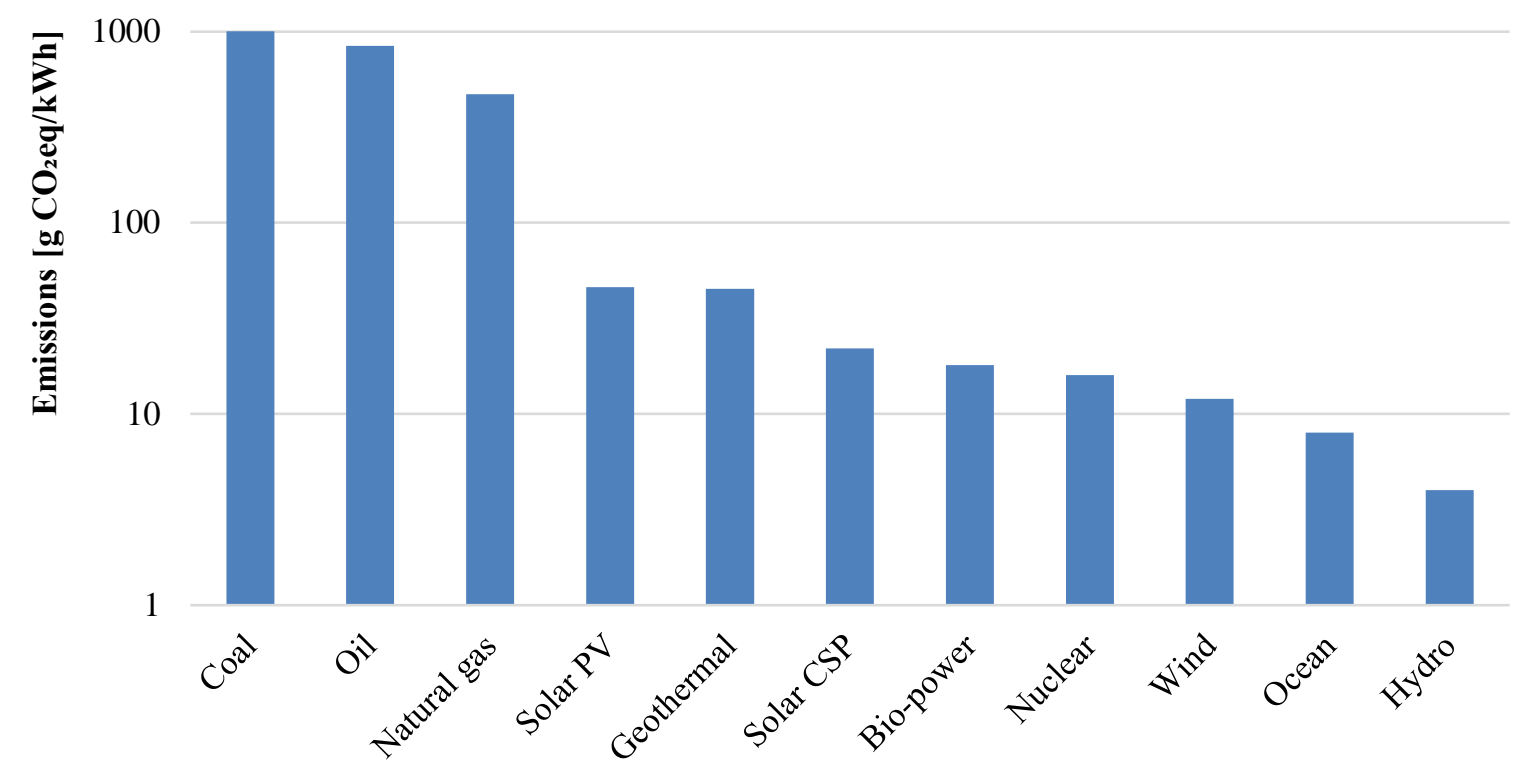

Electricity generation source

Figure 19: GHG Emissions by Source (Moomaw et al., 2011)

\subsection{Fuel economics}

Fossil-fuel, be it oil or gas, is subject to high-price volatility which is under the dictum of geopolitics, the most recent (March 2014) example being the price rise of 30\% for the supply of Russian gas to Ukraine. The fossil-fuel markets are prone to even minor wars or skirmishes. This phenomenon is presently demonstrated in Figure 20. In addition governments across the globe are striving to reduce GHG emissions by imposing a heavy tax on automobile fuel. Figure 21 illustrates such price rise for fuel delivered to the motorist, the UK fuel price rising by almost $100 \%$ within a decade. Figure 22 shows the electricity price rise with that of automobile fuel. A point worthy of note, though, is that electricity price is much more 'governable' as multiple sources contribute towards its generation, including renewables which are now contributing very significantly within the Scottish, British and Slovenian economies. 


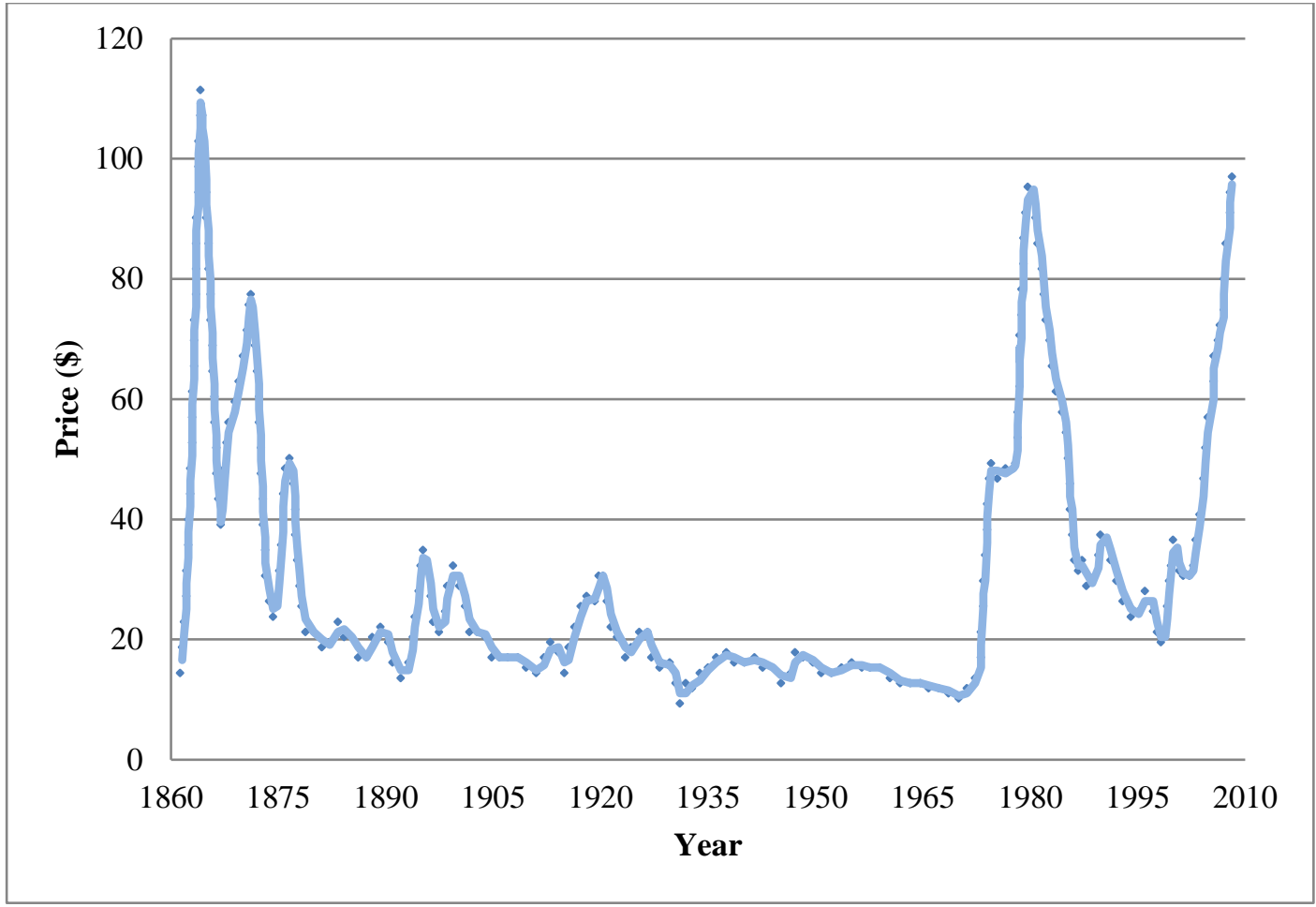

Figure 20: Real Price of Barrel of Petrol (2008 \$) (WTRG, 2011)

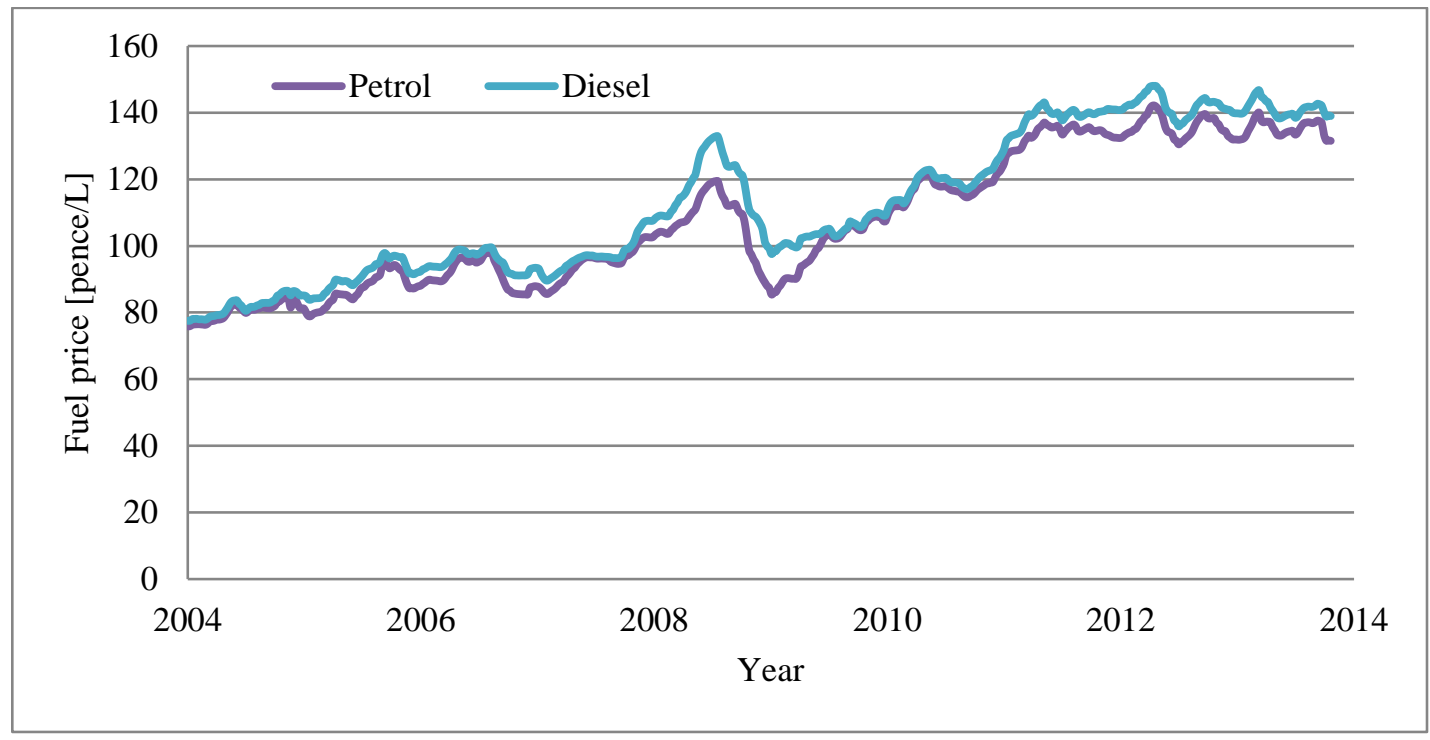

Figure 21: Weekly Fuel Pump Price in the UK (National Statistics, 2014) 


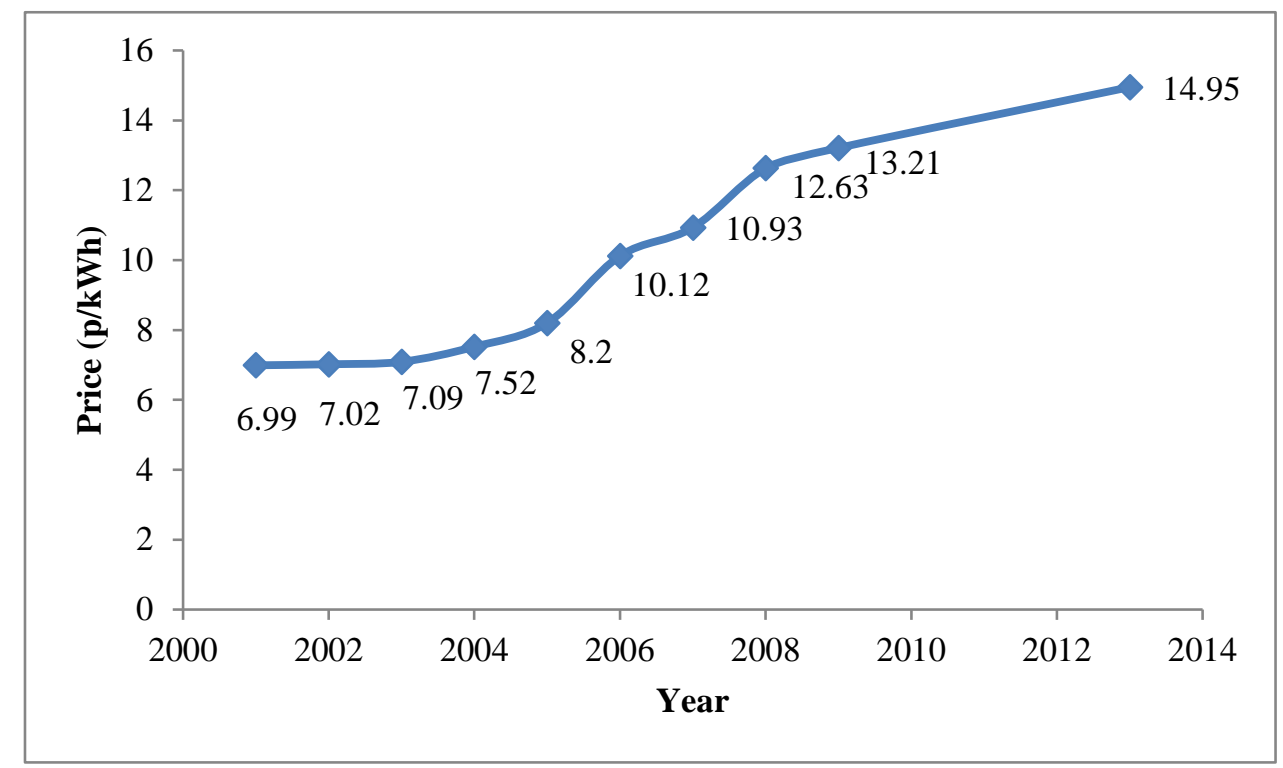

Figure 22: Electricity Domestic Price in the UK (HCL, 2014, AMDEA, 2014)

Worldwide there has been a concerted effort for installation of renewable energy systems as is evident in Table 1. Note that within UK the peak power capacities from newly installed solar plus wind sectors are now $33 \%$ of the respective total demand placed on the grid.

Table 1 Electricity Statistics for the World's Top 20 Countries with Highest Installed Power Capacity

\begin{tabular}{|l|c|c|}
\hline & & Year \\
\hline World's total power capacity, GW & 5064 & 2010 \\
\hline World's total energy generation, TWh & 22,200 & 2011 \\
\hline World's PV peak power capacity, GW & 136 & 2013 \\
\hline World's PV energy generation, TWh & 53 & 2011 \\
\hline World's wind peak power capacity, GW & 318 & 2013 \\
\hline World's wind energy generation, TWh & 378 & 2013 \\
\hline UK total peak power demand, GW & 44.4 & 2012 \\
\hline UK's PV peak power capacity, GW & 4 & 2014 \\
\hline UK's wind peak power capacity, GW & 10.5 & 2013 \\
\hline
\end{tabular}

Source: The Shift Project Data Portal, 2014.

If anything the pace of such installations seems to be accelerating. For example, for the solar sector the global newly installed PV capacity in the first quarter of 2014 reached 9 GW, up 35\% from the same period in 2013. The forecast is that the global newly installed PV capacity will exceed $50 \mathrm{GW}$ in the 12-month period from April 2014 to March 2015. The strong growth registered during the first quarter of 2014 was mainly driven by strong demand in Japan and the UK (Solarbuzz, 2014). 


\section{THE DEPLOYMENT OF ELECTRIC VEHICLES}

The first electric car was built in the 1830s by Robert Anderson in Scotland. Breakthrough by Gaston Plante and Camille Faure increased battery energy storage capacity, which led to the commercialization of battery-electric cars in France and Great Britain in the 1880s (Fernandes Serra, 2012).

Growing pollution, rising crude oil prices, depleting crude oil stock reserves, increasing environment awareness and government-backed incentives are pushing EV sales. With almost double mileage, less fuel consumption, lower running cost, silent operation and zero tail pipe emissions the EVs offer and attractive option, compared to petrol-engined vehicles. The number of EVs in the form of hybrid, plugin hybrid and fully electric vehicles is constantly rising due to the above mentioned reasons.

According to "Global \& United States Electric Vehicle Market Forecast \& Opportunities, 2017" the electric vehicles market will witness a phenomenal growth in the near future. Global EV industry clocked a turnover close to USD 54 Billion in 2011 (AS Reports, 2014). Global EV markets are growing at a much faster pace than anticipated previously. The global outlook for the EV market seems very promising due to an increase in overall consumer spending, growth in population, increasing demand for environment friendly vehicles and growing government support. These factors are expected to drive the EV market to new heightened figures in the near future. The success of the EV has not been immediate as concerns exist regarding the vehicles driving range. Figures show that in 2012 the average passenger car travels $13.7 \mathrm{~km}$ a day in the UK and in Scotland the average was $12.1 \mathrm{~km}$ (Keep and Rutherford, 2014, Transport Scotland, 2013). Transport Scotland (2013) reports that 96\% of all journeys in Scotland are less than 40km. Table 2 ('a' \& 'b') presents the technical specifications of the Renault Zoe electric car and Mitsubishi iMiev electric car. The authors have more than a year's experience of driving Renault Zoe electric car and Mitsubishi iMiev electric cars. These vehicles were the main subject of the present study.

Within the United Kingdom since the year 2010 a favourable policy has been adopted to promote sales of electric cars by way of providing a $£ 5,000$ subsidy towards the purchase. Figure 23 present's data for UK and Slovenia electric car registrations and Table 2 presents specifications for present fleet of EVs. The UK has seen a significant increase in the uptake of the EV; however, as can be seen in Figure 23 Slovenia is slower to adopt the EVs as an alternative to the ICVs. Further information is provided in Tables 2 and 3 on two electric car models that are available within Europe and the progressive evolution of efficiency of charging stations that has enabled a seven-fold reduction in charge time. 


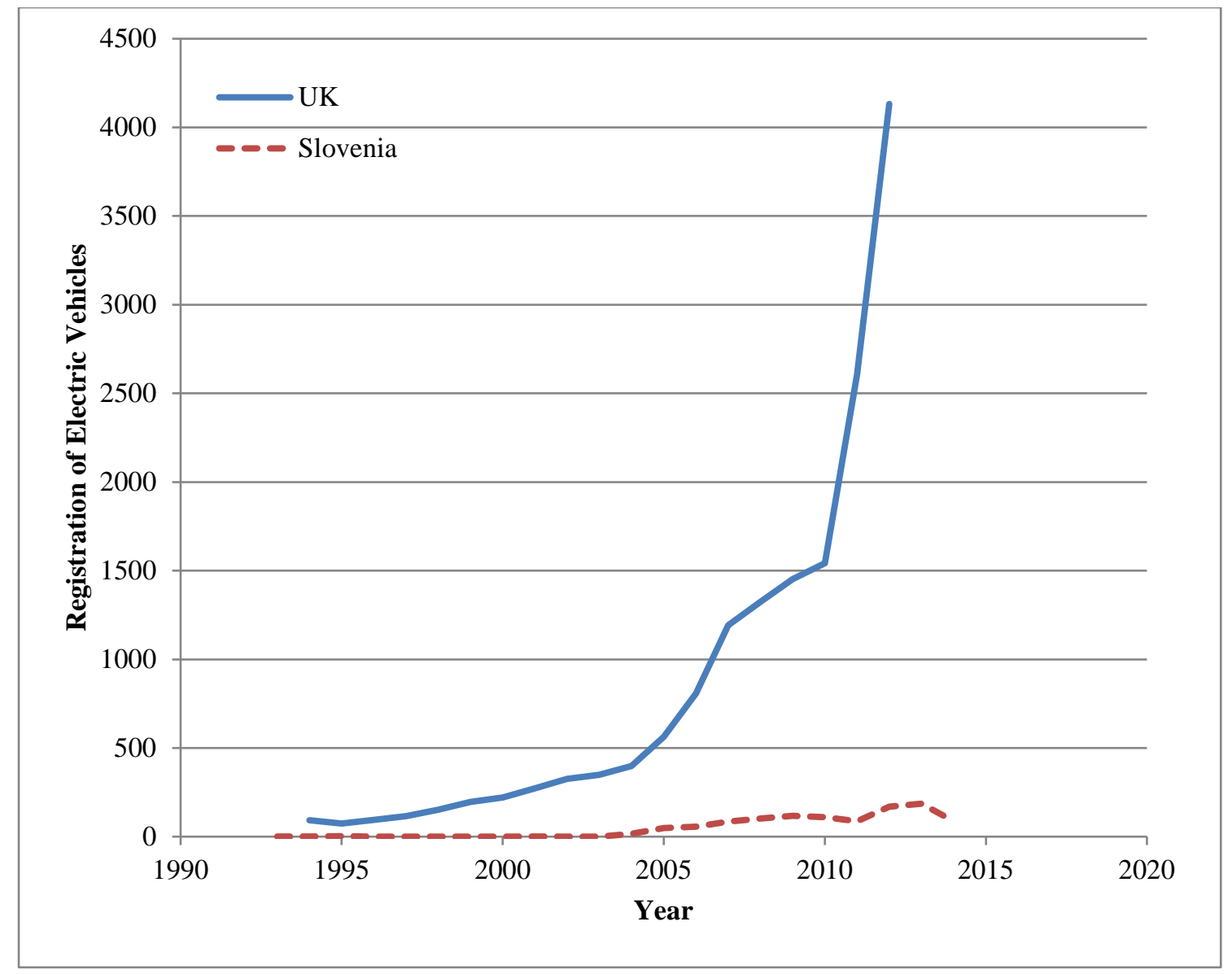

Figure 23: Registration of Electric Vehicles in the UK (Keep and Rutherford, 2014).

Figures 24-25 and Table 4 present data related to the range of battery size, driving range and motor power for electric cars that are now available. 


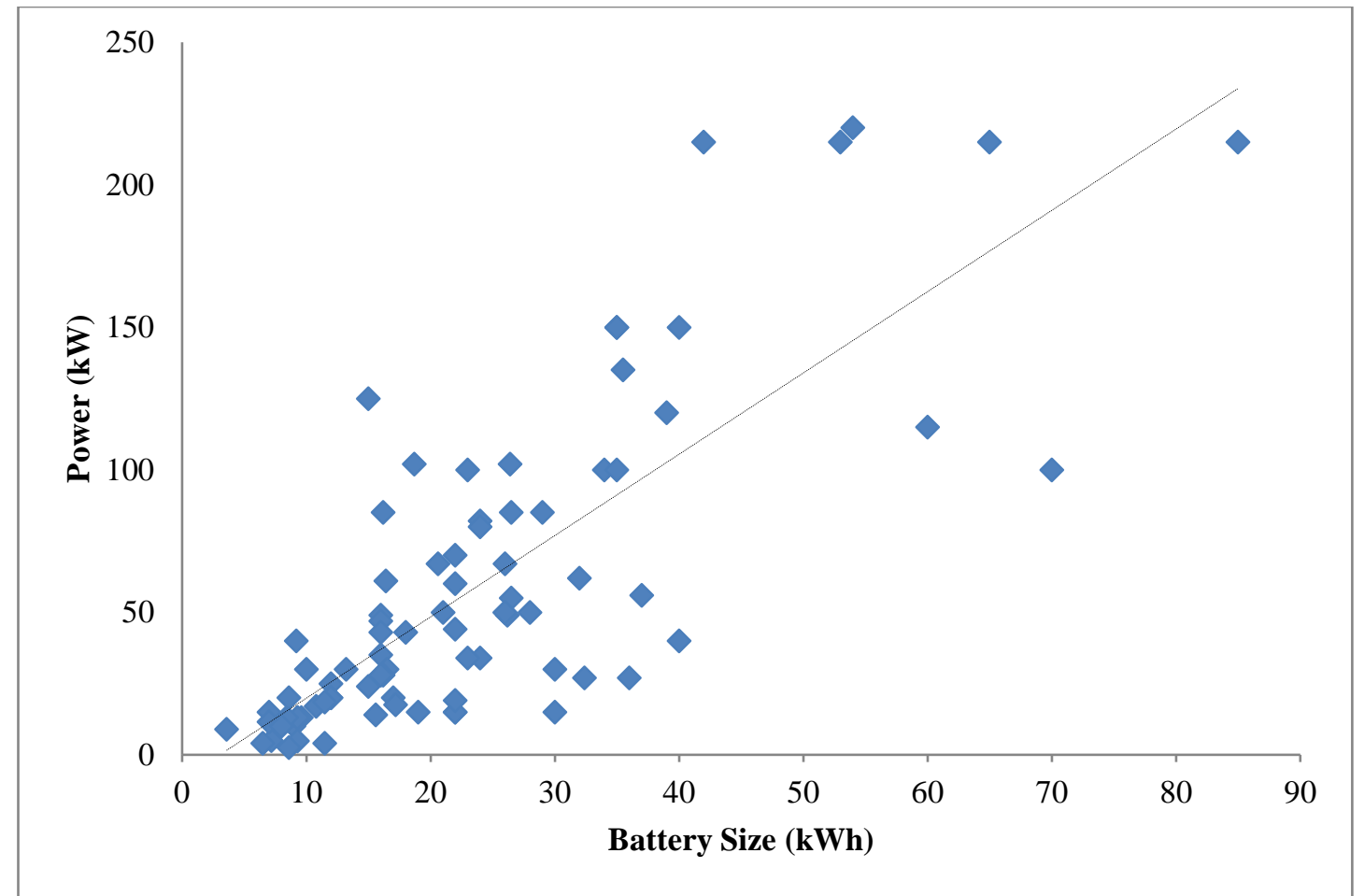

Figure 24: Battery Energy Capacity and Motor Power for Electric Vehicles (de Santiago et al., 2012)

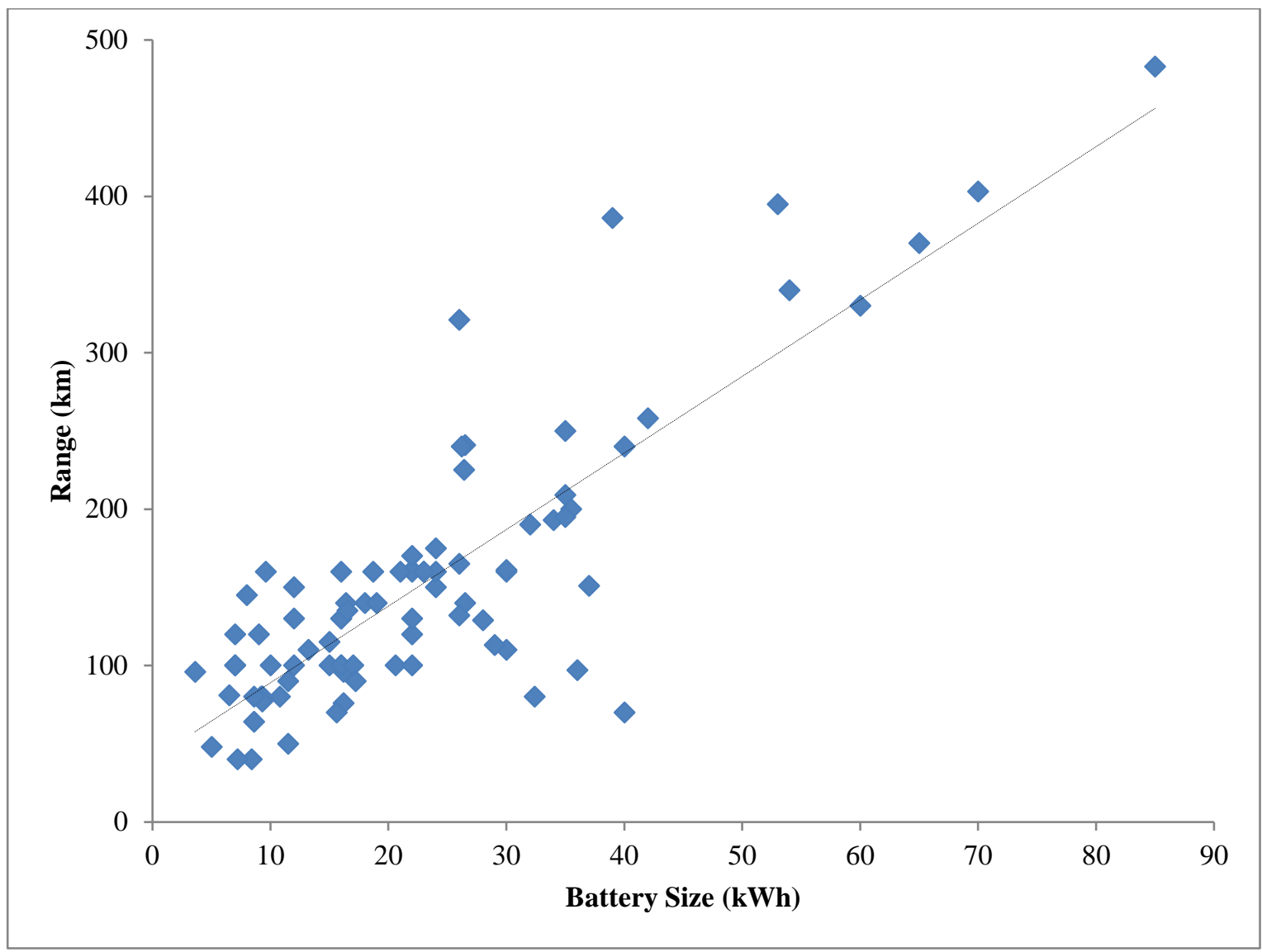

Figure 25: Battery Energy Capacity versus Range for Commercial Electric Vehicles (de Santiago et al., 2012) 
Table 2a Technical Specification for Renault Zoe

\begin{tabular}{|c|c|}
\hline \multicolumn{2}{|c|}{ TECHNICAL SPECIFICATIONS } \\
\hline ENGINE & \\
\hline Electric motor technology & Synchronous with rotor coil \\
\hline $\begin{array}{l}\text { EEC maximum power }[\mathrm{kW} / \mathrm{hp}] / \text { at } \\
\text { maximum rpm }\end{array}$ & $65(88)$ / 3,000 - 11,300 \\
\hline $\begin{array}{l}\text { EEC peak torque }[\mathrm{Nm}] \text { / at maximum } \\
\text { rpm }\end{array}$ & $220 / 250-2,500$ \\
\hline \multicolumn{2}{|l|}{ BATTERY } \\
\hline Technology & Lithium Ion \\
\hline Total voltage & 400 \\
\hline Number of modules / cells & $12 / 192$ \\
\hline On-board power [kWh] & 22 \\
\hline Battery weight $[\mathrm{kg}]$ & 290 \\
\hline \multicolumn{2}{|l|}{ CHARGING } \\
\hline Chameleon Charger & Single or three-phase / 3 - $43 \mathrm{~kW}$ \\
\hline \multirow[t]{3}{*}{ Charging time } & $3 \mathrm{~kW}=9 \mathrm{~h}$ \\
\hline & $22 \mathrm{~kW}=1 \mathrm{~h}$ (to $80 \%)$ \\
\hline & $43 \mathrm{~kW}=30 \mathrm{~min}$ (to $80 \%$ ) \\
\hline \multicolumn{2}{|l|}{ GEARBOX } \\
\hline Gearbox type & $\begin{array}{l}\text { Gearbox with single-speed } \\
\text { reduction gear bar }\end{array}$ \\
\hline Number of forward ratios & 1 \\
\hline \multicolumn{2}{|l|}{ PERFORMANCE } \\
\hline Top speed [mph] & 84 \\
\hline 0-30 mph / 0-60 mph & $4 \mathrm{~s} / 13.5 \mathrm{~s}$ \\
\hline \multicolumn{2}{|l|}{$\begin{array}{l}\text { EEC FUEL CONSUMPTION } \\
\text { Standard no. } 93 / 116\end{array}$} \\
\hline NEDC driving range [miles] & 130 \\
\hline $\begin{array}{l}\text { Likely driving range in suburban driving } \\
\text { [miles] }\end{array}$ & $62-90$ \\
\hline Standardized consumption $[\mathrm{Wh} / \mathrm{km}]$ & 146 \\
\hline $\mathrm{CO}_{2}[\mathrm{~g} / \mathrm{km}]$ & 0 \\
\hline \multicolumn{2}{|l|}{ WHEELS AND TYRES } \\
\hline Standard wheels rims ["] & 16 \\
\hline Tyre dimensions & $\begin{array}{l}\text { MICHELIN ENERGY E-V } \\
\text { tyres: 195/55 R16 }\end{array}$ \\
\hline \multicolumn{2}{|l|}{ AERODYNAMICS } \\
\hline Coefficient of drag & 0.272 \\
\hline \multicolumn{2}{|l|}{ WEIGHT } \\
\hline Unladen kerb weight & 1,468 \\
\hline Max. gross vehicle weight [GVW] & 1943 \\
\hline
\end{tabular}

Source: Renault, 2014.

Table 2b Technical Specifications for the Mitsubishi iMiev

\begin{tabular}{|l|c|}
\hline PERFORMANCE: & \\
\hline Engine type & Y51 Electric Motor \\
\hline Fuel type & Electric \\
\hline
\end{tabular}




\begin{tabular}{|l|c|}
\hline Max. Output kw (bhp) at rpm & 49 (66) / 4000-8000 \\
\hline Max. Torque Nm at rpm & 196 / 0-3000 \\
\hline Maximum speed mph (kph) & 81 (130) \\
\hline Battery (12v) type & $34 \mathrm{~B} 19 \mathrm{~L}$ (S) \\
\hline Battery (main traction) volts & 330 \\
\hline Battery (main traction) energy (kWh) & 16 \\
\hline EMISSIONS/ECONOMY: & \\
\hline $\begin{array}{l}\text { Electric use (weighted average } \\
\text { miles/Wh) }\end{array}$ & 4.6 \\
\hline Electric range Miles (km) & 160 (100) \\
\hline TRANSMISSION: & Automatic \\
\hline Transmission & Fixed gear ratio \\
\hline Automatic type & 7.065 \\
\hline Final gear ratio & 3475 x 1475 x 1610 \\
\hline DIMENSIONS: & 150 \\
\hline $\begin{array}{l}\text { Exterior length x width x height } \\
\text { (mm) }\end{array}$ & 1310 \\
\hline Ground clearance (unladen) (mm) & 1270 \\
\hline Front (mm) & 2550 \\
\hline Rear (mm) & \\
\hline Wheelbase (mm) & 4 \\
\hline WEIGHTS/VOLUMES: & 1450 \\
\hline Seating capacity & 1070 \\
\hline Gross vehicle weight (kg) & \\
\hline Kerb weight (kg) & \\
\hline
\end{tabular}

Source: Mitsubishi, 2014.

Table 3 Charging times for Renault, Zoe electric vehicle

\begin{tabular}{|l|c|c|c|c|c|}
\hline \multicolumn{7}{|c|}{ CHARGING TIMES } \\
\hline $\begin{array}{c}\text { Charger } \\
\text { Type }\end{array}$ & Phases & $\begin{array}{c}\text { Current } \\
{[\mathbf{A}]}\end{array}$ & $\begin{array}{c}\text { Voltage } \\
{[\text { [V] }}\end{array}$ & $\begin{array}{c}\text { Power } \\
{[\mathbf{k W ]}}\end{array}$ & $\begin{array}{c}\text { Charge } \\
\text { Time }\end{array}$ \\
\hline Very Slow & 1 & 10 & 230 & 2.3 & $9.5 \mathrm{~h}$ \\
\hline Slow & 1 & 16 & 230 & 3.7 & $6.0 \mathrm{~h}$ \\
\hline Fast & 1 & 32 & 230 & 7.4 & $3.0 \mathrm{~h}$ \\
\hline AC-Rapid & 3 & 32 & 230 & 22 & $1.0 \mathrm{~h}$ \\
\hline DC-Rapid & 3 & 63 & 230 & 43 & $0.5 \mathrm{~h}$ \\
\hline $\begin{array}{l}\text { Battery } \\
\text { Swap* }\end{array}$ & - & - & - & & $90 \mathrm{~s}$ \\
\hline
\end{tabular}

*Available for Tesla car in California

Source: Renault, 2014, Tesla, 2014.

Table 4 Specification of the Various EVs Currently available in the UK 


\begin{tabular}{|c|c|c|c|c|c|c|}
\hline $\begin{array}{l}\bar{\nabla} \\
\sum\end{array}$ & 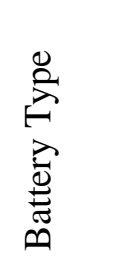 & 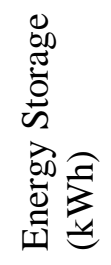 & 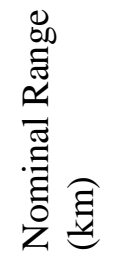 & 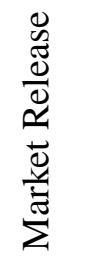 & 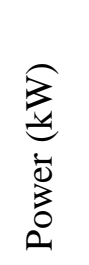 & $\begin{array}{l}\stackrel{0}{ٍ} \\
\stackrel{0}{\epsilon} \\
\stackrel{0}{0} \\
\stackrel{0}{\Sigma}\end{array}$ \\
\hline BMW i3 & $\mathrm{Li}$ & 22 & 150 & 2013 & 130 & - \\
\hline Tesla Model S & $\mathrm{Li}$ & 65 & 370 & 2012 & 215 & IM \\
\hline Hyundai BlueOn & $\mathrm{Li}$ & 16.4 & 140 & 2012 & 61 & PM \\
\hline Ford Focus Electric & $\mathrm{Li}$ & 23 & 160 & 2011 & 100 & IM \\
\hline Renault Fluence Z.E & $\mathrm{Li}$ & 22 & 161 & 2011 & 70 & SB \\
\hline Renault ZOE & $\mathrm{Li}$ & 22 & 160 & 2011 & 60 & SB \\
\hline Ford Tourneo Connect EV & $\mathrm{Li}$ & 21 & 160 & 2011 & 50 & IM \\
\hline Kangoo Express Z.E & $\mathrm{Li}$ & 22 & 170 & 2011 & 44 & SB \\
\hline Peugeot iOn & $\mathrm{Li}$ & 16 & 130 & 2011 & 35 & PM \\
\hline Renault Twizzy & $\mathrm{Li}$ & 7 & 100 & 2011 & 15 & - \\
\hline REVA NXR & $\mathrm{Pb}$ & 9.6 & 160 & 2011 & 13 & IM \\
\hline Nissan Leaf & $\mathrm{Li}$ & 24 & 175 & 2010 & 80 & PM \\
\hline Ford Transit Connect EV & $\mathrm{Li}$ & 28 & 129 & 2010 & 50 & IM \\
\hline Mitsubishi i-MiEV & $\mathrm{Li}$ & 16 & 160 & 2009 & 47 & $\mathrm{PM}$ \\
\hline Tesla Roadster & $\mathrm{Li}$ & 53 & 395 & 2008 & 215 & IM \\
\hline Smart ED & $\mathrm{Na}$ & 13.2 & 110 & 2007 & 30 & $\mathrm{PM}$ \\
\hline NICE Mega City & $\mathrm{Pb}$ & 6.5 & 81 & 2006 & 4 & $\mathrm{DC}$ \\
\hline G-Wiz & $\mathrm{Pb}$ & 9.3 & 77 & 2001 & 4.8 & DC \\
\hline General Motors EV1 & NiMh & 26.4 & 225 & 1999 & 102 & IM \\
\hline Peugeot 106 & NiCd & 12 & 150 & 1999 & 20 & DC \\
\hline Toyota RAV4 EV & NiMh & 26 & 165 & 1998 & 50 & $\mathrm{PM}$ \\
\hline Renault Express Electro & $\mathrm{Pb}$ & 22 & 100 & 1998 & 19 & - \\
\hline Enfield 8000 & $\mathrm{~Pb}$ & 8 & 145 & 1969 & 10 & $\mathrm{DC}$ \\
\hline
\end{tabular}

Battery Types:

$\mathbf{L i}$ - based on Lithium

$\mathbf{P b}$ - Lead Acid

Na - Sodium-nickel Chloride zebra batteries and sodium sulphur in Ford Ecostar

NiMh - Nickel-metal hydride

NiCd - Nickel Cadmium

Motor Types:

IM - Induction Motor

PM - Permanent Magnet Motor

SB - Synchronous Brush Motor

Source: de Santiago et al., 2012.

Research has shown that a complete electrification of the European fleet would only result in an additional demand on grid by up to 15\%. In Scotland, the year 2015 deadline has been set by Transport Scotland for 50mile charge points along all principal routes.

The Scottish government has committed to almost complete decarbonisation of the road transport sector by 2050. As such a major element of this transformation will be a shift towards the electrification of road transport. A sustainable fleet of electric vehicles aligns with Scottish investment in a renewable energy sector. After all, 
a quarter of Europe's tidal and offshore wind potential lies in Scotland. Scotland has set itself a most ambitious target to acquire 'the equivalent of all of Scotland's electricity needs to come from renewable sources by 2020'. A resolution has therefore been approved for the deployment of rapid charge points at intervals of at least 50 miles on Scotland's primary road network to enable extended all-electric journeys. Furthermore, there is a $100 \%$ funding for the installation of home charging points (Transport Scotland, 2013).

Likewise, the UK Committee on Climate Change (2010) suggested that 16\% of new car sales by 2020 would need to be plug-in vehicles. On a broader scale the European Commission (2011), in its White Paper of Transport set out to:

- Halve the use of 'conventionally-fuelled' cars in urban transport by 2030

- Phase them out in cities by 2050

- Achieve essentially $\mathrm{CO}_{2}$-free city logistics in major urban centres by 2030 .

The main drivers for the above actions have been identified as:

- Climate change

- Energy security through exploitation of renewable energy resource

- Air quality and noise pollution

- Public health

- Economic opportunities and job creation.

The first models of electric cars that were made available within the UK were Nissan Leaf and Mitsubishi iMiev. Now all of the mainstream car manufacturers provide EVs within their model range.

In 2011 Edinburgh College acquired electric cars for supporting inter-site staff travel. This was followed by Edinburgh Napier University acquiring a Renault Zoe EV. The two educational institutions have also installed EV charging points at each of their campuses. The third partner of this study - Maribor University of Slovenia - hosts a Faculty of Logistics which is in the process of setting up an electric vehicle research program. A brief account of the relevant activities is provided below.

Edinburgh College are playing a leading role in monitoring 16 EVs which have been leased. There are a total of twenty four charging points, two located at each campus and the remainder at strategic locations to serve their business use. The EVs are for staff use only and for Corporate College business embedded into the company's fleet travel plan. The College has leased the EVs since 2011 with the first year operating as a trial period, following full roll out of vehicles to the four main campuses. Trials are still frequently undertaken to understand the efficiency of the vehicles in serving the operational needs of the staff at the College.

Staff can book an electric car through a simple booking system available on the College's intranet site. Out of the 1,200 staff working at the college, 400 have signed up to use these cars. The typical workforce using the vehicles comprises workplace assessors and staff who undertake lectures at various places. Should the member of staff wish it, training is available for new staff and ongoing support to existing staff as the car models change.

Currently the Milton Road campus has the highest demand for electric car use, with the Sighthill campus having the lowest demand. Notwithstanding this, given the nature of activity, the usage of the electric cars at each of the College campuses fluctuates throughout the academic year. Whilst there is a booking system in place which records journey lengths, their origins and destinations, it is difficult to identify if there have been many occurrences of staff trying to book a car and being unsuccessful due to a lack of availability of cars. Table 5 provides an illustration of College electric vehicle usage since 2011. 
Table 5 Edinburgh College EV Usage

\begin{tabular}{|c|c|c|c|}
\hline Year/Month & $\begin{array}{c}\text { Sum of } \\
\text { Bookings }\end{array}$ & $\begin{array}{c}\text { Sum of } \\
\text { Trips }\end{array}$ & $\begin{array}{c}\text { Sum of } \\
\text { Distance }\end{array}$ \\
\hline $2011 / 11$ & 0 & 343 & 1,220 \\
\hline $2011 / 12$ & 0 & 277 & 971 \\
\hline $2012 / 01$ & 0 & 293 & 900 \\
\hline $2012 / 02$ & 0 & 420 & 1,286 \\
\hline $2012 / 03$ & 0 & 500 & 1,623 \\
\hline $2012 / 04$ & 0 & 290 & 1,242 \\
\hline 2012/05 & 3 & 394 & 1,334 \\
\hline $2012 / 06$ & 2 & 281 & 1,198 \\
\hline $2012 / 07$ & 0 & 82 & 207 \\
\hline 2012/08 & 22 & 184 & 831 \\
\hline $2012 / 09$ & 54 & 425 & 1,513 \\
\hline $2012 / 10$ & 75 & 503 & 1,626 \\
\hline 2012/11 & 71 & 381 & 1,347 \\
\hline $2012 / 12$ & 58 & 274 & 1,034 \\
\hline $2013 / 01$ & 73 & 416 & 1,799 \\
\hline 2013/02 & 67 & 355 & 1,425 \\
\hline 2013/03 & 88 & 464 & 1,775 \\
\hline 2013/04 & 106 & 485 & 2,290 \\
\hline 2013/05 & 101 & 544 & 2,082 \\
\hline 2013/06 & 54 & 357 & 1,538 \\
\hline 2013/07 & 72 & 511 & 2,857 \\
\hline 2013/08 & 60 & 444 & 2,586 \\
\hline 2013/09 & 86 & 538 & 3,184 \\
\hline $2013 / 10$ & 82 & 490 & 2,963 \\
\hline 2013/11 & 93 & 488 & 2,321 \\
\hline 2013/12 & 81 & 418 & 2,505 \\
\hline 2014/01 & 88 & 491 & 2,852 \\
\hline $2014 / 02$ & 85 & 401 & 2,755 \\
\hline $2014 / 03$ & 101 & 389 & 1,911 \\
\hline Totals & 1522 & 11438 & 51,174 \\
\hline
\end{tabular}

\section{Previous Work Related to Performance of Electric Cars}

Experimental test data obtained by US Lab on regenerative efficiency of motors/generators is shown in Figure 26. Using the information presented in the latter figure and noting that for the Renault Zoe model which has a motor of $65 \mathrm{~kW}$ (88hp) capacity, for a fractional load in excess of 0.2 the motor/generator performs with high efficiency that is in excess of $97 \%$. However for very low vehicle speeds with the fractional load below $20 \%$ the efficiency curve drops sharply. Hence in a vehicle such as the Renault Zoe the control algorithm stops regenerative braking below $9 \mathrm{mph}$ on level ground. 




Figure 26: Three-Phase Induction Motor/Generator Efficiency Profile (U.S. Department of Energy, 2001)

For the Renault Zoe model which has a machine of $65 \mathrm{~kW}$ (88hp) capacity, for a fractional load in excess of 0.2 the motor/generator performs with high efficiency that is in excess of $97 \%$. However for very low vehicle speeds with the fractional load below $20 \%$ the efficiency curve drops sharply. Hence in a vehicle such as the Renault Zoe the control algorithm stops regenerative braking below 9 mph on level ground. Holmberg et al. (2012) have shown that in passenger cars, one-third of the fuel energy is used to overcome friction in the engine, transmission, tyres, and brakes. The direct frictional losses, with braking friction excluded, were reported to be equivalent to $28 \%$ of the fuel energy. In total, $21.5 \%$ of the fuel energy is used to move the car (Holmberg et al., 2012). They have also estimated that friction-related energy losses in an electric car are only about half those of a fossil-fuelled car. Based on a survey of global fleet of automobiles that were manufactured in the year 2000 Holmberg et al. have presented the following data for an average vehicle: 75-kW four-cylinder 1700-CC engine, $1500 \mathrm{~kg}$ weight, $70 \%$ gasoline fuelled and 30\% diesel fuelled, and 8litre/100km average fuel consumption. Using the above survey of literature they have also reported the following audit for fuel energy dissipation: $33 \%$ to exhaust gases, $29 \%$ to coolant, 38\% to mechanical energy which may be further sub-divided into $5 \%$ to overcome air drag and 33\% to overcome friction in the car. The part of the fuel energy devoted to mechanical energy to overcome friction can then be further subdivided as $35 \%$ to overcome tyre's rolling friction, 35\% to overcome friction in the engine system, $15 \%$ to overcome friction in the transmission and $15 \%$ to overcome brake-contact friction. They have also presented data on tyre rolling friction coefficients on paved roads and these are 0.013 for production year 2000, 0.007 for 2010 and 0.001 for 2020. In the presented simulation a friction coefficient of 0.013 was used.

Howey et al. (2011) present the measured energy consumption results of a range of efficient vehicles with the test undertaken over a 57 mile urban / extra-urban route. The results show that on average the EVs used the least amount of energy, i.e. $0.172 \mathrm{kWh} / \mathrm{km}$ or $0.275 \mathrm{kWh} / \mathrm{mile}$, followed by the hybrid electric vehicles (HEV) $(0.32 \mathrm{kWh} / \mathrm{km})$. The internal combustion engine vehicles (ICV) used 0.75 $\mathrm{kWh} / \mathrm{km}$. The hydrogen fuel-cell vehicle used $0.33 \mathrm{kWh} / \mathrm{km}$. An estimate of $\mathrm{CO}_{2}$ emissions was also made and it was found that hybrids gave the lowest $\mathrm{CO}_{2}$ emissions, with around half of the vehicles emitting less than $70 \mathrm{gCO}_{2} / \mathrm{km}$. The most efficient diesel combustion engine vehicles emitted about 80 $\mathrm{gCO}_{2} / \mathrm{km}$ but the majority exceeded $110 \mathrm{gCO}_{2} / \mathrm{km}$. The majority of EVs emitted $70-110 \mathrm{gCO}_{2} / \mathrm{km}$ assuming a United Kingdom grid average emission factor of $542 \mathrm{gCO}_{2} / \mathrm{kWh}$ (Howey et al., 2011).

The latterly mentioned research team have also experimentally obtained the mean discharging $\left(\eta_{d}\right)$ and charging $\left(\eta_{c}\right)$ efficiencies of kinetic energy recovered from braking for the EV and found these to be $99 \%$ 
AC Propulsion (2011) and BRUSA 2011 report a battery charging efficiency of $\eta_{\mathrm{bc}}=90-95 \%$ for a 3kW single phase supply. In this study, therefore, a mean value of $92.5 \%$ has been assumed for the latter efficiency. The total trip energy may thus be obtained from equation 1 ,

Energy $=\frac{1}{\eta_{b c}}\left[\frac{1}{\eta_{d}} E_{\text {Traction }}-\eta_{c} E_{\text {Regeneration }}\right]$

Another set of test data on the energy consumption of 'Modec' EVs is provided by McKay (2009). Based on a test run of $46.6 \mathrm{~km}$ the energy measured at the battery was found to be $0.36 \mathrm{kWh} / \mathrm{km}$ or $0.58 \mathrm{kWh} / \mathrm{mile}$. However, note that the driving cycle included vehicular speeds of up to $77.5 \mathrm{kmph}$ along dual-carriageways and the frontal area and drag coefficient for the Modec, which is a load bearing minitruck, were excessively large. The above mentioned efficiencies for $\eta_{\mathrm{d}}, \eta_{\mathrm{c}}$ and $\eta_{\mathrm{bc}}$ for the Modec vehicle were cited as $0.7,0.7$ and 0.95 respectively.

Boretti (2013) undertook dynamometer tests on a Nissan 'Leaf' EV with the view to ascertain propulsion (traction) and regenerative braking efficiencies. The tests were conducted for cold- and hot cycles, respectively at atmospheric temperatures of $6.7^{\circ} \mathrm{C}$ and $22.2^{\circ} \mathrm{C}$. The reported values for $\eta_{\mathrm{d}}$ and $\eta_{\mathrm{c}}$ for the above test conditions, respectively, were $57.3 \%$ and $26.6 \%$, and $89.6 \%$ and $79 \%$.

The specific energy consumption for the above vehicle for the above set of atmospheric temperatures was also reported as 0.371 - and $0.194 \mathrm{kWh} / \mathrm{mile}$. All of these data were for partially discharged battery.

Acha et al. (2011) undertook a comparison of the well-to-wheels and vehicle life cycle emissions from matched mid-sized SUV-class ICV, HEV and EV for Californian market. A 15-year vehicle life and $19,300 \mathrm{~km} /$ year travel distance was assumed. Their findings may be summarised as follows. The wellto-wheels emissions were found to be 163,114 and 55 grams $\mathrm{CO}_{2} / \mathrm{km}$ while the life cycle emissions were 38, 41 and 55grams $\mathrm{CO}_{2} / \mathrm{km}$ (Ma et al., 2012). The analysis was based on an average electricity grid intensity of 144 grams $\mathrm{CO}_{2} / \mathrm{kWh}$. In a subsequent section of this article the latter analysis shall be revisited with the proviso that renewable electricity is used for charging and production of EVs.

\section{THE VEHICLE DYNAMICS AND ENERGY CONSUMPTION (VEDEC) SIMULATION SOFTWARE AND ITS VALIDATION}

The present team has developed simulation software that is capable of calculating power and energy requirements for any vehicle during driving. The origin of this development lies in a contractual work that was undertaken by members of the present team for the City of Edinburgh Council's Transport Department (Esteves-Booth et al., 2001). The software also computes energy savings that are achievable from regenerative braking system when compared directly with the energy requirements of the same vehicle without such system. Simulations take detailed account of energy consumed during level cruise, acceleration and gradient-climbing modes. The right hand side of Equation 2 has components of energy that include, from left to right, tyre friction, hill climbing, wind drag and change in kinetic energy.

$E=\left[\mu m g \cos \theta+m g \sin \theta+\frac{1}{4} C_{d} A \rho\left(v_{f}^{2}+v_{i}^{2}\right)\right] \Delta d+\frac{1}{2} m\left(v_{f}^{2}-v_{i}^{2}\right)$

For the purpose of energy auditing topography data may be keyed-in using topography maps or directly logged using an on-board altimeter. 
Table 6 presents the Mapometer software validation results which are based on the present study undertaken by this research team. A comparison was made of of the measured/computed energy for sixteen trial runs undertaken on the experimental electric vehicle (Renault, ZOE). The vehicle is supplied with on-board display of energy consumption data for traction and air-conditioning as well as energy replenished to battery during regenerative braking. Note that during excessively hard braking frictional-braking process assists energy replenishment and therefore the latter audit of energy is not fool-proof.

Figure 28 shows the route map and altitude ascending or descending information that can be generated for the experimental vehicle respectively. There is a GPS sensor provided by 'Masternaut' company of Leeds, England (Masternaut, 2014) and 'Mapometer' software (Mapometer, 2014). The accuracy referred in Table 7 and Figure 27 is herein defined as (Equation 3),

$$
\text { Accuracy }=\frac{\text { Energy }_{\text {simulation }}}{\text { Energy }_{\text {measured }}}
$$

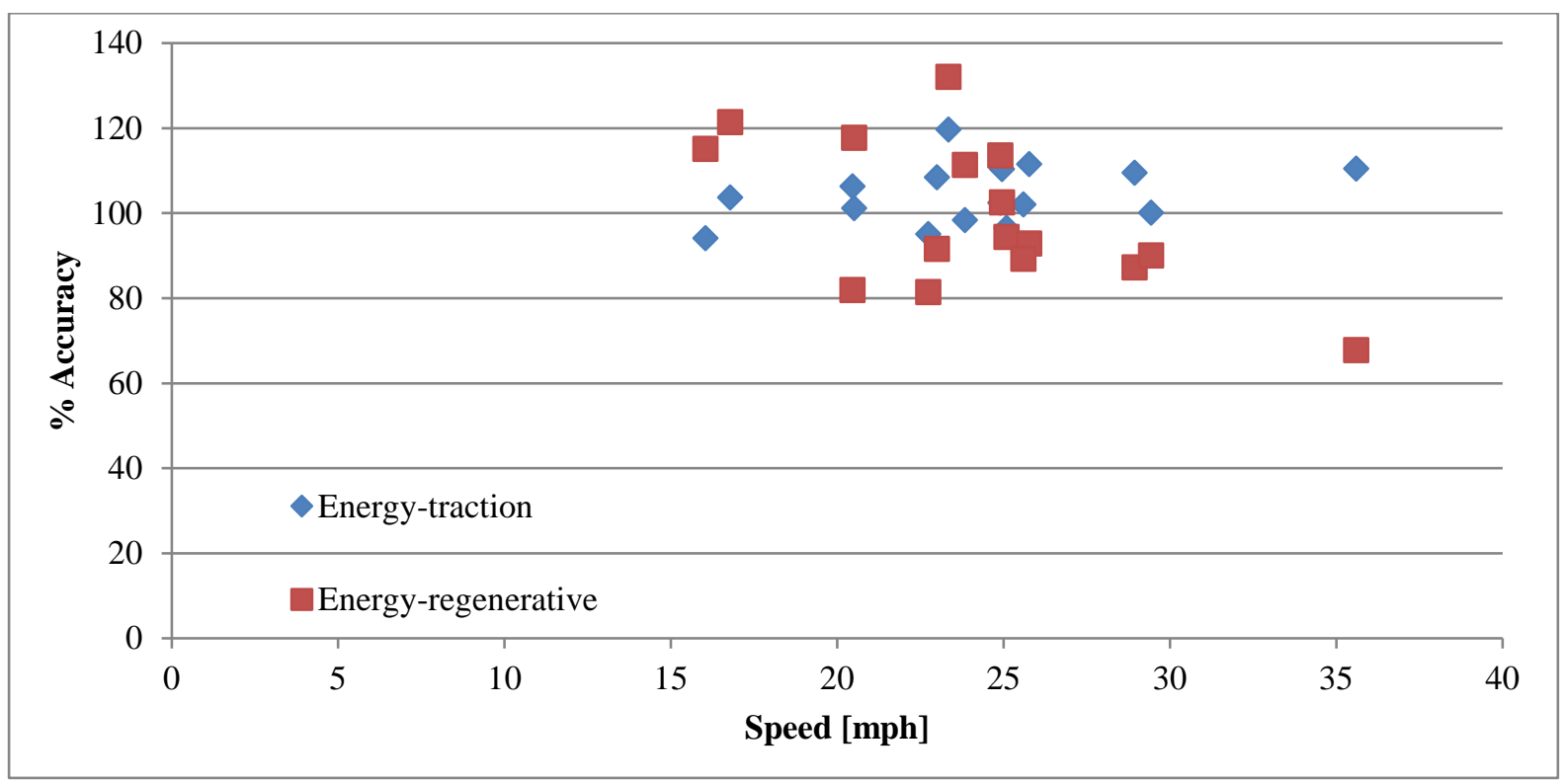

Figure 27: Validation of VEDEC Software

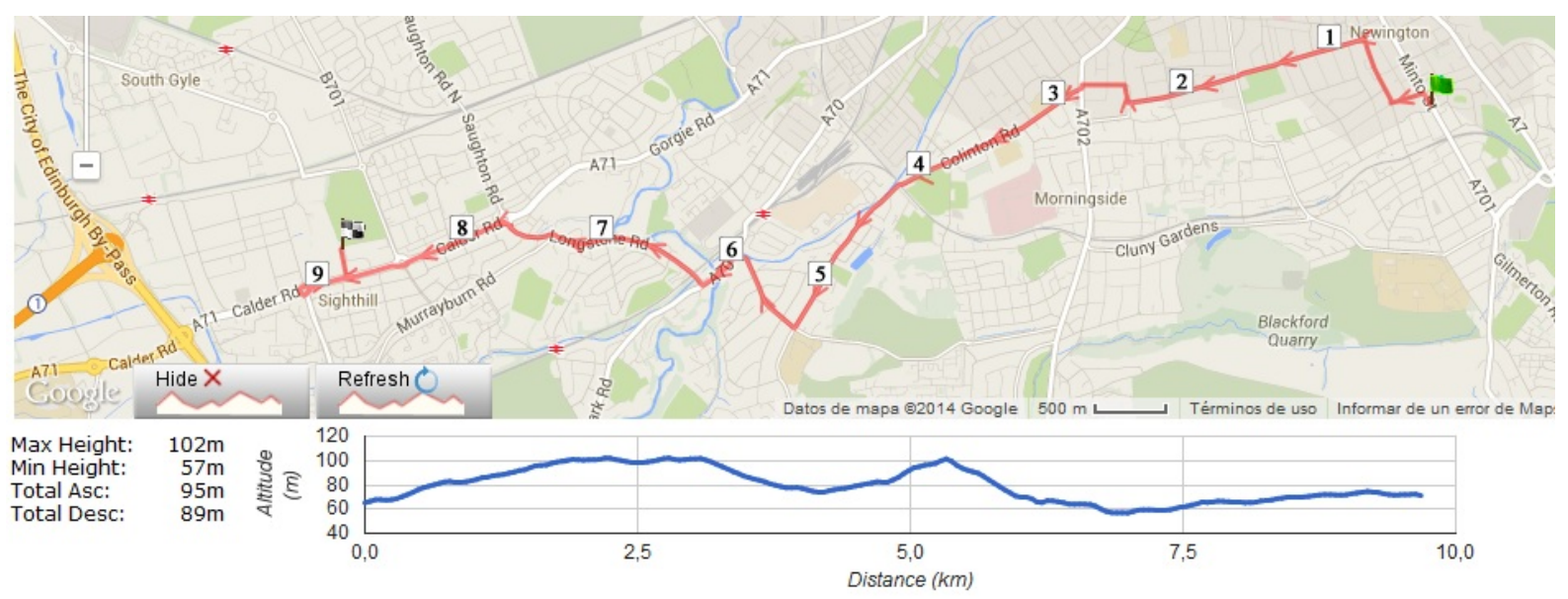

Figure 28: 'Mapometer' Generated Route and Altitude Profile (See Table 7 test run \#3), Mapometer, 2014 
Table 6 Validation of 'Mapometer' Software for Distance and Altitude

\begin{tabular}{|c|c|c|c|c|c|c|}
\hline \multirow{2}{*}{ EXPERIMENT } & \multicolumn{2}{|c|}{ Measured Values } & \multicolumn{2}{c|}{ Mapometer Values } & \multicolumn{2}{c|}{ Accuracy } \\
\cline { 2 - 7 } & Distance [m] & Altitude [m] & Distance [m] & Altitude [m] & Distance & Altitude \\
\hline $\mathbf{1}$ & 1276.5 & 73.8 & 1280 & 78 & $\mathbf{1 0 0 . 3}$ & $\mathbf{1 0 5 . 7}$ \\
$\mathbf{2}$ & 421.6 & 33.4 & 430 & 33 & $\mathbf{1 0 2 . 0}$ & $\mathbf{9 8 . 8}$ \\
\hline
\end{tabular}

In the latter figure the data related to traction efficiency is shown as diamonds while the squares present the results for regenerated energy. Note that based on the information presented in Figure 26 an average motor efficiency of $85 \%$ for the traction- and $55 \%$ for regeneration modes have been respectively assumed. This is owing to the fact that the experimentally determined maximum speed on a level motorway was recorded as 88 miles per hour and this was taken as full load for the motor. Table 7 indicates an average speed range of 16- to $35.6 \mathrm{mph}$ which corresponds to a load variation of 18 to $40 \%$ of full-load which in turn corresponds to an efficiency increase from 93 to $98 \%$ (see Figure 27). Note that there will be further losses within the battery, at the battery connectors and mechanical losses. Hence an overall assumed efficiency of 85\% incorporated within the VEDEC software seems to produce satisfactory results as shown in Figure 27.

Table 7 Test Runs Undertaken for Renault Zoe

\begin{tabular}{|c|c|c|c|c|c|c|c|c|}
\hline \multirow[b]{2}{*}{ EXP N } & \multirow[b]{2}{*}{ Route } & \multirow[b]{2}{*}{$\begin{array}{c}\text { Average } \\
\text { Speed } \\
\text { [mph] }\end{array}$} & \multicolumn{2}{|c|}{ Simulation } & \multicolumn{2}{|c|}{ Experiment } & \multicolumn{2}{|c|}{ Computational Accuracy } \\
\hline & & & $\begin{array}{c}\text { E-used* } \\
\text { [kWh] }\end{array}$ & $\begin{array}{c}\text { E-reg*** } \\
{[\mathrm{kWh}]}\end{array}$ & $\begin{array}{c}\text { E- } \\
\text { used } \\
\text { [kWh] }\end{array}$ & $\begin{array}{l}\text { E-reg } \\
\text { [kWh] }\end{array}$ & $\begin{array}{l}\text { Traction } \\
\text { Accuracy }\end{array}$ & Reg Accuracy \\
\hline 1 & Morningside-Leith & 17 & 1.14 & 0.36 & 1.1 & 0.3 & 104 & 121 \\
\hline 2 & Leith-Morningside & 16 & 1.41 & 0.23 & 1.5 & 0.2 & 94 & 115 \\
\hline 3 & Home-Sighthill & 25 & 2.12 & 0.47 & 2.2 & 0.5 & 97 & 94 \\
\hline 4 & Sighthill-Home & 36 & 3.32 & 0.48 & 3 & 0.7 & 111 & 68 \\
\hline 5 & Home-Greens & 23 & 1.33 & 0.33 & 1.4 & 0.4 & 95 & 82 \\
\hline 6 & Greens-Home & 20 & 1.49 & 0.33 & 1.4 & 0.4 & 106 & 82 \\
\hline 7 & Home-Costco & 24 & 1.67 & 0.22 & 1.7 & 0.2 & 98 & 112 \\
\hline 8 & Costco-ESR & 26 & 1.00 & 0.37 & 0.9 & 0.4 & 112 & 93 \\
\hline 9 & Napier-Sighthill & 25 & 1.21 & 0.31 & 1.1 & 0.3 & 110 & 103 \\
\hline 10 & Sighthill-Napier & 25 & 1.33 & 0.23 & 1.3 & 0.2 & 102 & 114 \\
\hline 11 & Napier-Dalkeith & 26 & 2.96 & 0.80 & 2.9 & 0.9 & 102 & 89 \\
\hline 12 & Home-Arthur & 23 & 0.65 & 0.18 & 0.6 & 0.2 & 109 & 92 \\
\hline 13 & Arthur-Arthur (Slow) & 23 & 1.08 & 0.26 & 0.9 & 0.2 & 120 & 132 \\
\hline 14 & Arthur-Arthur (Fast) & 29 & 1.31 & 0.35 & 1.2 & 0.4 & 110 & 87 \\
\hline 15 & $\begin{array}{l}\text { Arthur-Shop } \\
\text { Bruntsfield-Juniper }\end{array}$ & 20 & 0.91 & 0.12 & 0.9 & 0.1 & 101 & 118 \\
\hline 16 & Green-Bruntsfield & 29 & 2.42 & 0.51 & 2.5 & 0.6 & 97 & 85 \\
\hline
\end{tabular}

*Energy used for traction, **Energy recovered by regenerative braking.

Regarding the regenerative efficiency, Figure 27 shows a decreasing profile for the accuracy calculations. Note that the computation of regenerative efficiency is further complicated by the fact that the manufacturers limit the capture of braking energy to avoid severe braking, i.e. many drivers prefer 
to 'coast' rather than decelerate even if the latter results in increased efficiency. There is a balance to be maintained between efficiency and drive comfort. For example in the earlier models of Nissan Leaf electric car only a 30\% regenerative efficiency was set by the manufacturer. In the present version of VEDEC software and in consultation with research undertaken by Boretti (2013) and U.S Department of Energy (2001) a regenerative efficiency value of 55\% was found to be optimum. It could well be the case that for higher speeds the manufacturer's algorithm reduces the efficiency of regeneration for the sake of drive comfort. In this respect an attempt was made to obtain further information from the manufacturers (Renault of France) but those attempts were futile.

Bearing in mind the profile of Figure 26 the decreasing behaviour of reported calculation accuracy of regenerative energy, shown in Figure 27 may be explained as follows. During braking the average speed will drop to much lower values than those reported for the overall journey. Thus, for much lower speeds the efficiency of regeneration would in real terms drop quite significantly. With an assumed average efficiency of 55\% the computed regeneration energy would thus be in excess of the actual generated quantity. The accuracy figures would thus appear in excess of $100 \%$. At much higher vehicular speeds the opposite would be true, i.e. accuracy figures would thus be lower than $100 \%$.

\section{BATTERY RECHARGING USING GRID-ELECTRICITY}

The evolutionary development of electric battery charging for the electric car was highlighted in Table 3. Presently, experiments were conducted to collect data related to battery charge as a function of time. These data are shown in Figures 29 and 30, respectively for the two experimental cars i.e. Renault Zoe and Mitsubishi iMiev. Figure 29 can be explained through a 'mating analogy', when a battery is charging or discharging from full capacity the reactivity in the battery is high as there are a large proportion of ions to react together (or pair up) initially. However, after some time reactivity is much lower as the concentration of reactants decreases (fewer suitors to pair up with), which results in charging time taking longer or the ability of the car to accelerate will decrease in the battery discharging mode. This analogy gives a simple explanation to why Figure 29 does not continue its linear trend and becomes more asymptotic at $97 \%$ charge and above. Figure 30 compares the performance of three generations of charging stations and demonstrates the remarkable developments related to faster charging. Note however that the record is presently held by Tesla Motors with a 90 seconds battery swap shown in Table 3. 


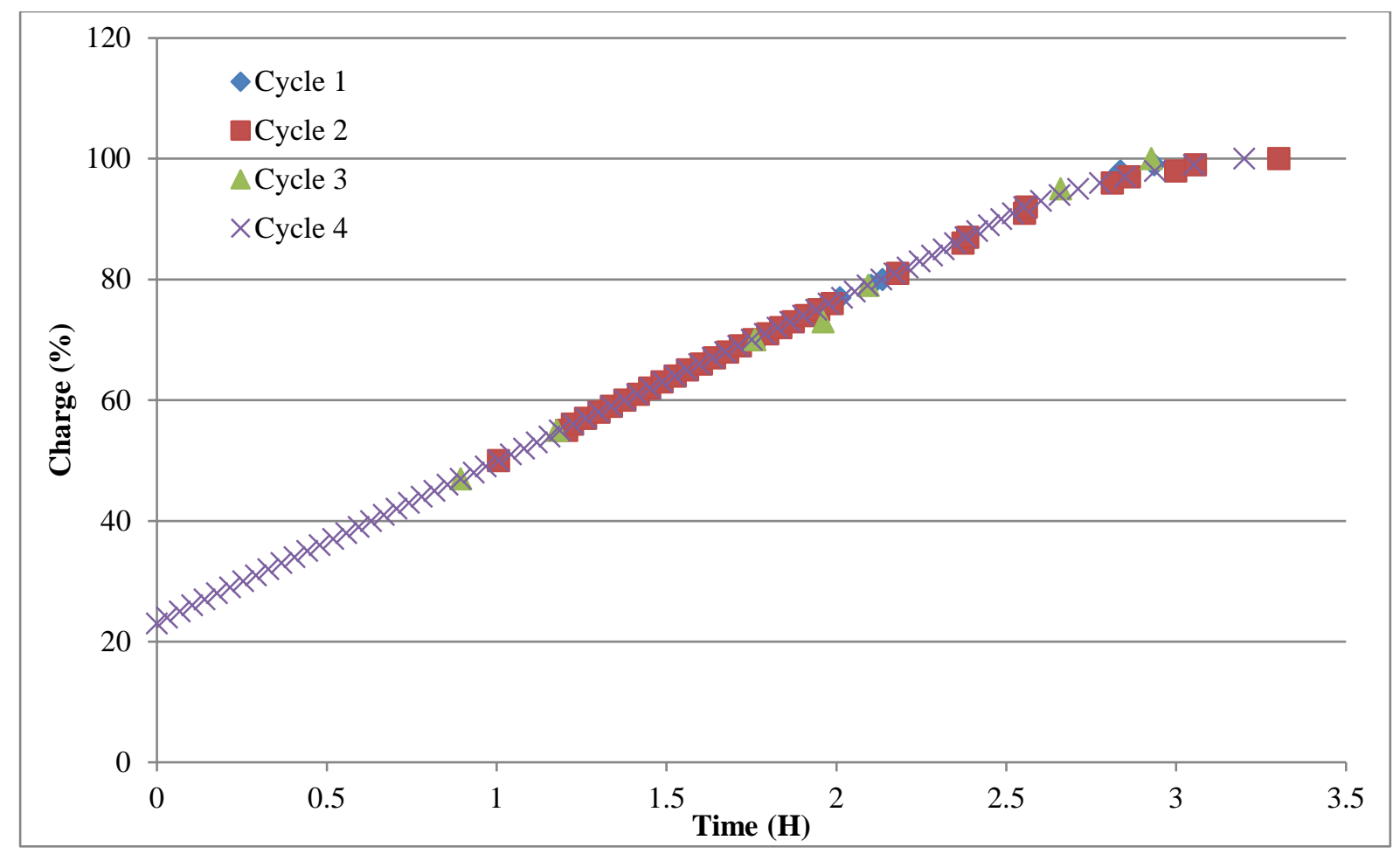

Figure 29: Renault Zoe (22kWh) Battery Charging Profile (Fast Charger)

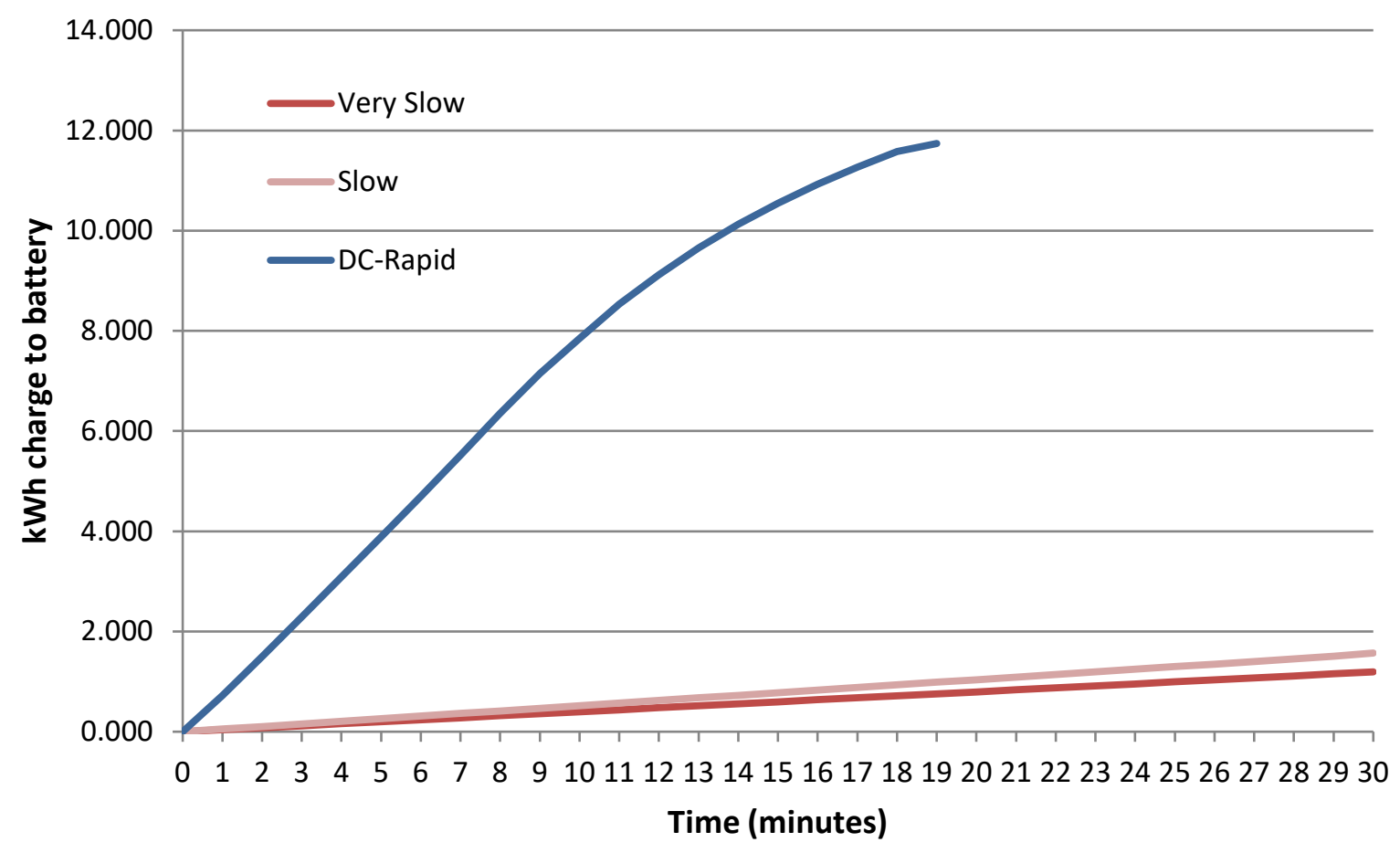

Figure 30: Mitsubishi iMiev (16kWh) battery charging Profile data for Three Different Charges

\section{THREE 'E’ ANALYSIS}


A Three 'E' analysis is a holistic analysis that investigates Energy, Economic and Environmental impacts of a project. The Renault Zoe model was purchased by the present research team for $£ 13,670$ which after government top-ups has a total price of $£ 18,670$. Table 8 shows the three costs that are the subject of this section. In this respect reference is made to Fig. 19. The $\mathrm{CO}_{2}$ emissions for nuclear, hydro and wind generated electricity are respectively 16-, 4- and 12grams $\mathrm{CO}_{2} / \mathrm{kWh}$, Furthermore, Fig. 18 presented data for electricity generated (GWh) by source for Scotland. The present proportions are coal/oil/gas (36\%), nuclear (37\%), hydro (11\%) and other renewables that chiefly include wind (17\%). If, the Scottish Government plans to completely decarbonise emissions from road vehicles achieved by year 2020 then the $\mathrm{CO}_{2}$ emissions will drop by two orders of magnitude as shown in Table 8 .

Table 8 Three 'E’ analyses for the Renault Zoe electric car

\begin{tabular}{|l|c|}
\hline Energy used $(\mathrm{kWh} / \mathrm{km})$ & 0.164 \\
\hline Energy used (kWh/mile) & 0.262 \\
\hline & pence/mile \\
\hline Electricity cost & 3.15 \\
\hline Battery cost & 0.78 \\
\hline Servicing cost & 0.04 \\
\hline Vehicle depreciation cost & 33.16 \\
\hline Total economic cost & 37.12 \\
\hline CO2-emissions & g/mile \\
\hline Charging based on UK grid & 142 \\
\hline $\begin{array}{l}\text { Charging based on Solar PV } \\
\text { (see Figs. 18 and 19) }\end{array}$ & 12 \\
\hline
\end{tabular}

\section{RENEWABLE ENERGY RECHARGING}

The two factors that will bring about a significant change in the present day unsustainable aspect of transport sector are market inducements for the introduction of EVs and a sustainable supply of electricity for charging them. In this respect a very brief review of the policy of the UK central and local governments is presently discussed. Firstly, the introduction of electric vehicles is being encouraged by an offer of $£ 5,000$ by the UK Government towards the purchase of new electric vehicles, the total cost of which has dropped from an average of $£ 27,500$ to $£ 19,000$.

Historically, members of this research team have been engaged in the development of a medium-tolarge scale solar PV generation facility. Table 8 present details of those installations hosted by the two educational institutes. A life-cycle audit of Edinburgh Napier University installation (Muneer et al., 2006) indicated an intensity of 44 grams of $\mathrm{CO}_{2} / \mathrm{kWhe}$. It was shown in Table 1 that UK and Scotland are poised to take the renewable energy progression forward with enthusiasm. The UK is now the sixth nation in the world with the highest PV capacity. On a per capita basis, the UK PV installations are ten 
times more than global average. That is indeed a remarkable achievement given that the average annual receipt of solar radiation is only $40 \%$ of that reported for the equatorial arid regions. Furthermore, Scotland appears to be on track to achieve its goal of $100 \%$ non-fossil fuel electricity by 2020 , i.e. by year 2013, 6.6GW of wind capacity is to be installed with a further 14GW of consented capacity. These facts may now be borne in mind to examine the carbon intensity estimates presented in Table 8 . Thus, a reduction from 130grams of $\mathrm{CO}_{2}$ emissions from the present fleet of fossil-fuel automobiles to 3.3grams of $\mathrm{CO}_{2}$ from renewable energy sourced electrical charged vehicles is probable. The UK aims to cover $15 \%$ of its domestic electricity demand with renewables by 2020 . As part of this goal, the DECC aims to have 22 GW of installed PV capacity by the end of the decade (UK Government, 2014). In 2013 Slovenia installed $0.8 \mathrm{GW}$ of renewable energy capacity (EY, 2014) with $0.1 \mathrm{GW}$ in the pipeline and a goal of $25 \%$ of energy consumption in the country by 2020 supplied from renewable resources.

\section{CONCLUSIONS}

Literature has shown that the severity of environmental problems require a global, international and national attention. A link can be made between the increase in human population, increase in $\mathrm{CO}_{2}$ emissions, increase in ambient and in ocean temperatures. The authors propose the EV is a solution to reducing $\mathrm{CO}_{2}$ emissions in the transport sector in moving towards a more sustainable future as it is the second largest contributor of these harmful gases after the energy generation sector. This paper concludes the following:

- Renault reports a power usage of $0.146 \mathrm{Wh} / \mathrm{km}$, however, experimental finding show that the car returned a consumption figure of $0.164 \mathrm{Wh} / \mathrm{km}, 12 \%$ more than reported values.

- The efficiency figures for the motor and generator were obtained as 0.85 and 0.55 respectively.

- Two large-scale solar PV projects that are based in Edinburgh were monitored by the present team. The Edinburgh Napier University wall mounted facility has a $15 \mathrm{kWp}$ capacity and produced a total of $62.68 \mathrm{MWh}$ in 9.06 years, thus averaging $461 \mathrm{kWh}$ per year, per $\mathrm{kWp}$ capacity. Likewise, the seven-acre, $620 \mathrm{kWp}$ solar farm operated by the Scottish and Southern Electricity (SSE) on behalf of Edinburgh College produced 435MWh in its first year of operation. Its production intensity was thus $702 \mathrm{kWh} /$ year-kWp. This work has indicated an energy use figure of $576 \mathrm{kWh} /$ annum for the monitored electric car. Thus the respective numbers of cars that can be sustained by the above installations are 12 and 755 .

- The UK grid electricity $\mathrm{CO}_{2}$ intensity is presently 542 gram/kWh. However, for locallygenerated wind and solar PV electricity that figure drops to 11 - and $44 \mathrm{gram} / \mathrm{kWh}$. Hence it makes ‘Carbon' sense to plan for charging of electric vehicles from renewable sources. Hence a very significant investment would be required for the introduction of electric car fleet within the national economy. The latter solar $\mathrm{PV} \mathrm{CO}_{2}$ intensity figure was obtained by the present team from monitoring of significantly large PV installations around Edinburgh.

- The purchase price of the Renault Zoe is $£ 18,670$ which after Government’s contribution has a total price to the consumer of $£ 13,670$. After taking account of a $60 \%$ drop in the resale value of the vehicle after 3 - and $80 \%$ after 5 years and an audit of battery charging/leasing and vehicle servicing the total cost was 37.12 UK pence per mile. The cost of electricity to charge the battery was found to be 3.15 pence per mile.

- Research and development of the EV battery technology is moving at a rapid pace and reduction in battery costs will prevail in the future. However, this is a barrier that is yet to be overcome. Renault is currently offering a battery leasing plan to their customers to make this an affordable option for the future.

- Likewise, the residual value of the EV needs further attention as it is imperative that a method is developed to calculate the resale value of these vehicles. 
- For the driver to get the optimum usage and experience it is important that fleet management is put in place to ensure efficient vehicle usage.

- The evolution of recharging has moved very rapidly with the slow charging, which took up to 9.5 hours, being reduced now to an hour.

- The VEDEC simulation program developed by this research team showed an average error of $4.4 \%$ for calculating traction- and $0.6 \%$ for regenerated energy.

\section{REFERENCES}

1. AC Propulsion, 2011. Available from: http://www.acpropulsion.com/faqs.html [Accessed 3 Feb 2014].

2. Acha, S., Green, T. C., \& Shah, N. (2011). Optimal Charging Strategies of Electric Vehicles in the UK Power Market. In Proceedings of IEEE PES ISGT 2011. Anaheim, CA, USA. 17th 19th January 2011.

3. AMDEA, 2014. Electricity Prices. Available from: http://www.t2c.org.uk/savingenergy/electricity-prices/ [Accessed 21 April 2014].

4. ASDReports, 2014. Global \& United States Electric Vehicles Market Forecast \& Opportunities, $2017 . \quad$ Available from: https://www.asdreports.com/shopexd.asp?id=60558\&utm_source=GEW\&utm_medium=affili ate\&utm campaign=GEW Rightblock\&utm content=title tekstlink [Accessed 25 April 2014].

5. Boretti, A., 2013. Analysis of the regenerative braking efficiency of a latest electric vehicle. SAE International: Society of Automotive Engineers, 2013. Paper \# 2013-01-2872.

6. BRUSA, 2011. NLG5 Battery Charger User's Manual. Available from: www.brusa.biz [Accessed 3 Feb 2014].

7. CCC, (Committee on Climate Change), 2010. The Forth Carbon Budget Reducing emissions through the 2020s. Available from: http://www.theccc.org.uk/publication/the-fourth-carbonbudget-reducing-emissions-through-the-2020s-2/ [Accessed 27 April 2014].

8. Committee on Climate Change (2010) Fourth Carbon Budget Review - technical report. Sectoral analysis of the cost-effective path to the 2050 target. Available from: http://www.theccc.org.uk/wp-

content/uploads/2013/12/1785bCCC_TechRep_Singles_Chap5_1.pdf [Accessed 13 May 2014.]

9. de Santiago, J., Bernhoff, H., Ekergård, B., Eriksson, S., Ferhatovic, S. et al., 2012. "Electrical Motor Drivelines in Commercial All Electric Vehicles: a Review" IEEE Transactions on Vehicular Technology, 61(2): 475-484. Available from: http://dx.doi.org/10.1109/TVT.2011.2177873 [Accessed 12 May 2014.]

10. DECC (Department of Energy and Climate Change), 2014. 2013 UK greenhouse Gas Emissions, Provisional Figures and 2012 UK Greenhouse Gas Emissions, Final Figures by Fuel Type and End-User. Available from: https://www.gov.uk/government/publications/provisional-uk-emissions-estimates [Accessed 26 April 2014].

11. Department for Transport, 2013. Greenhouse gas emissions by transport mode: United Kingdom, 1999-2011. Available from: ttps://www.gov.uk/government/uploads/system/uploads/attachment_data/file/265439/env020 1.xls [Accessed 25 April 2014].

12. Department for Transport, 2013a. Transport Statistics Great Britain 2013. Available from: https://www.gov.uk/government/publications/transport-statistics-great-britain-2013 [Accessed 26 April 2014].

13. EEA (European Environment Agency), 2010. GHG trends and projections in Slovenia. Available from: http://www.google.co.uk/url?sa=t\&rct=j\&q=\&esrc=s\&source=web\&cd=4\&ved=0CEIQFjAD \&url=http\%3A\%2F\%2Fwww.eea.europa.eu\%2Fpublications\%2Fghg-trends-and-projections- 
2012\%2Fslovenia.pdf\&ei=rhBFU4fXGIyQhQemuoHADA\&usg=AFQjCNFtfyUadPhcmWz2 asA33WDccBCuaw\&sig2=ZMoyBxX [Accessed 25 April 2014].

14. EEA (European Environment Agency), 2014. Final energy consumption by transport modes. Available from: http://www.eea.europa.eu/data-and-maps/daviz/final-energy-consumption-bytransport/\#tab-chart_1 [Accessed 26 March 2014].

15. Emmott, S., 2013. 10 Billion. London : Penguine, 198 pp.

16. Engineering Toolbox, 2014. Solubility of Gas in Water. Available from: http://www.engineeringtoolbox.com/gases-solubility-water-d 1148.html [Accessed 21 March 2014].

17. Esteves-Booth A., Muneer T ., Kirby H., Kubie J., Hunter J. (2001) The measurement of vehicular driving cycle within the city of Edinburgh. Transportation Research Part D, pp. 209220.

18. European Commission, 2011. The white paper of transport. Roadmap to a single European transport area - Towards a competitive and resource-efficient transport system. Available from: http://ec.europa.eu/transport/themes/strategies/2011_white_paper_en.htm [Accessed 13 May 2014.]

19. European Commission, 2011. White paper on transport. Available from: http://www.google.si/url?sa=t\&rct=j\&q=\&esrc=s\&source=web\&cd=2\&ved=0CCkQFjAB\&u rl=http\%3A\%2F\%2Fec.europa.eu\%2Ftransport\%2Fthemes\%2Fstrategies\%2Fdoc\%2F2011_ white_paper\%2Fwhite-paper-illustrated-brochure_en.pdf\&ei=TnXXU7-

LFKjNygPHi4LwCg\&usg=AFQjCNGKA0nQbtXAwpyylT42fZRluVHbhg\&sig2=gjfDfpqXc_elRV8SRvaHA\&bvm=bv.71954034,d.bGQ [Accessed 7 May 2014.]

20. EY, 2014. Global renewable energy country attractiveness and resource map. s.l.: Global Cleantech Center, 2014. EYG no. LI015778.

21. Fenandes Serra J.V., 2012. Electric vehicles. Technology, policy and commercial development. Earthscan, New York.

22. HCL, 2014. Energy Prices. Available from: http://www.parliament.uk/briefingpapers/sn04153.pdf\%E2\%80\%8E [Accessed 21 April 2014].

23. Hemingway J., Michaels C., 2012. Electricity Generation and supply figures for Scotland Wales Northern Ireland and England, 2008 to 2011. pp. 50-58.

24. Hemingway, J., Michaels, C., 2012. Electricity Generation and supply figures for Scotland Wales Northern Ireland and England, 2008 to 2011. pp. 50-58.

25. Holmberg, K., Andersson, P., Erdemir, A., 2012. Global energy consumption due to friction in passenger cars. Tribology International, 47, doi:10.1016/j.triboint.2011.11.022 pp. 221-234.

26. Holmberg, K., Andersson, P., Erdemir, A., 2012. Global energy consumption due to friction in passenger cars. Tribology International; (47) pp. 221-234, doi:10.1016/j.triboint.2011.11.022.

27. Holyrood Renewables, spring 2014, issue 7. Published by Scottish Renewables, Scotland (www.holyrood.com).

28. Howey, D.A., Martinez-Botas, R.M., Cussons, B., Lytton, L., 2011. Comparative measurements of the energy consumption of 51 electric, hybrid and internal combustion engine vehicles. Transportation Research D, 2011. DOI 0.1016/j.trd.2011.04.001.

29. IEA (International Energy Agency), 2012. $\mathrm{CO}_{2}$ Emissions from fuel Combustion Highlights. Luxembourg : IEA Publications, 2012.

30. International Energy Agency (IEA), 2012. Monthly Electricity Statistics July 2012. Available from: www.iea.org/stats/surveys/MES.xls [Accessed 25 April 2014].

31. IPCC, 2007. Contribution of working Group I to the Forth Assessment Report of the Intergovernmental Panel on Climate Change. Available from: http://www.ipcc.ch/publications_and_data/publications_ipcc_fourth_assessment_report_wg1 report_the_physical_science_basis.htm [Accessed 25 April 2014].

32. Keep, M. and Rutherford, T., 2014. Passenger Transport. Available from: www.parliament.uk/briefing-papers/sn02660.pdf [Accessed 19 April 2014].

33. Leibling, D., 2008. Car Ownership in Great Britain. London: Royal Automobile Club Foundation for Motoring. 
34. Levitus S., Antonov J.I., Boyer T.P., Baranova O.K., Garcia H.E., Locarnini R.A., Zweng M.M., 2012. World ocean heat cintent and thermosteric sea level change (0-2000 m), 19552010. s.l.: Geophysical Research Letters, 2012, Vol. 39.

35. Ma, H., Balthasar, F., Tait, N., Riera-Palou X., Harrison, A, 2012. A new comparison between the life cycle greenhouse gas emissions of battery electric vehicles and internal combustion vehicles. Energy Policy (44) pp. 160-173., 2012.

36. Mackay, D.J.C., 2009. Sustainable Energy: Without the Hot Air. s.l.: UIT Cambridge , 2009. ISBN 0-9544529-3-3.

37. Mapometer, 2014. Route Information. Available from: http://gb.mapometer.com/ [Accessed 25 April 2014].

38. Masternaut, 2014. Vehicle Tracking. Available from: http://www.masternaut.co.uk/ [Accessed 25 April 2014].

39. Mitchell, W. J., Borroni-Bird, C. E., \& Burns, L. D., 2010. Reinventing the automobile (1st ed.). Cambridge, MA, USA: The MIT Press.

40. Mitchell, W. J., Borroni-Bird, C. E., Burns, L. D., 2010. Reinventing the automobile. (1st ed.), Cambridge, MA, USA: The MIT Press.

41. Mitsubishi, 2014. Mitsubishi Motors. i-Miev Technology. Available from: http://www.mitsubishi-cars.co.uk/imiev/technology.aspx [Accessed 2 May 2014].

42. Moomaw, W., Burgherr, P., Heath, G., Lenzen, M., Nyboer, J., Verbruggen, A., 2011. Annex II: Methodology. In IPCC Special Report on Renewable Energy Sources and Climate Change Mitigation [Edenhofer, O., Pichs-Madruga, R., Sokona, Y., Seyboth, K., Matschoss, P., Kadner, S., Zwickel, T., Eickemeier, P., Hansen, G., Schlomer, S., C. von Stechow (eds)], Cambridge University Press, Cambridge, United Kingdom and New York, NY, USA.

43. Morice, C., Kennedy, J., Rayner, N., Jones P., 2012. Quantifying uncertainties in global and regional temperature change using an ensemble of obsertational estimates.: Journal of Geographical Research, 2012, 117(D8).

44. Morice, C., Kennedy, J., Rayner, N., Jones, P., 2012. Quantifying uncertainties in global and regional temperature change using an ensemble of observational estimates. Journal of Geographical Research, 2012. 117(D8).

45. MUMM, $2014 . \quad$ North Sea Facts. Available from: http://www.mumm.ac.be/EN/NorthSea/facts.php [Accessed 25 April 2014].

46. Muneer T., Younes S., Lambert N., Kubie J., 2006. Life cycle assessment of a medium-sized photovoltaic facility at a high latitude location. IMechE, J. Power and Energy, Part A, 2006, Vol. 220. DOI: 10.1243/09576509JPE253.

47. National Grid, 2014. Metered half-hourly electricity demands. Available from: http://www.nationalgrid.com/uk/Electricity/Data/Demand\%2BData/ [Accessed 21 April 2014].

48. National Statistics, 2014. Weekly Fuel Prices. Available from: http://www.statistics.gov.uk/hub/release-

calendar/index.html?newquery $=* \&$ lday $=0$ \&lmonth $=0$ \&lyear $=0 \&$ title $=$ Weekly + Fuel + Prices \& pagetype $=$ calendar-entry\&uday $=$ \&umonth $=$ \&uyear $=$ [Accessed 22 April 2014].

49. OECD (The Organisation for Economic Co-operation and Development), 2011. Electricity Generation. Available from: http://www.oecd-ilibrary.org/sites/factbook-2011en/06/01/04/06-01-04-f1.html?itemId=/content/chapter/factbook-2011-49-en [Accessed 29 March 2014].

50. Office for National Statistics, 2011. 2011 Census - Population and Household Estimates for England and Wales, March 2011. Available from: www.ons.gov.uk/ons/dcp171778_270487.pdf [Accessed 1 May 2014.]

51. Renault, 2014. My Renault Zoe. Charging. Available from: http://myrenaultzoe.com/index.php/zoe-description/charging/ [Accessed 25 April 2014].

52. Renault, 2014. Renault Zoe Simply Revolutionary Drive for Change. Available from: http://www.google.si/url?sa=t\&rct=j\&q=\&esrc=s\&source=web\&cd=1\&ved=0CBwQFjAA\& url=http\%3A\%2F\%2Fmyrenaultzoe.com\%2FDocs\%2FZoeBrochure UK.pdf\&ei=A1zXU9q uBoP9ywOtxIHIBw\&usg=AFQjCNFvnqp3dEBrX0DFMiJvL9PK9OElLg\&sig2=nwW60is7f b3A8CISibZ10w [Accessed 22 April 2014]. 
53. Solarbuzz, 2014. Solar Market Research and Analysis. Available from: http://www.solarbuzz.com/ [Accessed 3 April 2014].

54. SURS, (Statistical Office of the Republic of Slovenia), 2014. Number of Population and natural change of population, Slovenia, annually. Available from: http://pxweb.stat.si/pxweb/Dialog/varval.asp?ma=05A2010E\&ti=\&path=../Database/Demogr aphics/05_population/05 Basic data/10 05A20 Population_A/\&lang=1 [Accessed 25 April 2014].

55. SURS, (Statistical Office of the Republic of Slovenia), 2014a. Passenger Transport and traffic, Slovenia. [Online] 2014. Available from: http://pxweb.stat.si/pxweb/Dialog/varval.asp?ma=2221101s\&ti=\&path=../Database/Ekonoms ko/22_transport/01_22211_transport_panoge/\&lang=2 [Accessed 25 April 2014].

56. SURS, (Statistical Office of the Republic of Slovenia), 2014b. Road vehicles at the end of the year (31.12.) By Vehicle tupe, Slovenia, annually. Available from: http://pxweb.stat.si/pxweb/Dialog/varval.asp?ma=2222105S\&ti=\&path=../Database/Ekonoms ko/22_transport/08_22221_reg_cestna_vozila/\&lang=2 [Accessed 24 March 2014].

57. Tesla, 2014. Battery Swap. Available from: http://www.teslamotors.com/en GB/batteryswap [Accessed 25 April 2014].

58. The Scottish Government, 2012. Electricity Generation and Supply. Available from: http://www.scotland.gov.uk/Publications/2012/03/2818/4 [Accessed 7 May 2014.]

59. The Shift Project Data Portal, 2014. Countries with highest installed power capacity. Available from: http://www.tsp-data-portal.org/TOP-20-Capacity\#tspQvChart [Accessed 7 May 2014.]

60. The Guardian, 2010. Salmond claims 100\% green electricity in Scotland 'achievable' by 2025. Available from: http://www.theguardian.com/environment/blog/2010/sep/28/salmond-greenelectricity-scotland [Accessed 3 May 2014.]

61. Transport Scotland, 2013. Switched On Scotland : A Roadmap to Widespread Adoption of Plug-in Vehicles Switched On Scotland : A Roadmap to Widespread Adoption of Plug-in Vehicles. pp. 1-82.

62. Transport Scotland, 2013. Switched on Scotland: A roadmap to widespread adoption of plugin vehicles, Crown Copyright, UK.

63. U.S. Department of Energy, 2001. Determining Electric Motor Load and Efficiency. 2001.

64. UK Government, 2014. Renewables. Table 6.4. Solar photovoltaics deployment. Available from: http://www.gov.uk/government/uploads/system/uploads/attachment data/fi [Accessed 2 May 2014.]

65. WardsAuto, 2014. World Vehicle Population Tops 1 Billion Units. [Online] 2014. Available from: http://wardsauto.com/ar/world_vehicle_population_110815 [Accessed 25 April 2014].

66. World Bank, 2014. Road Transport. Available from: http://search.worldbank.org/all?qterm=road+transport [Accessed 25 March 2014].

67. WTRG, 2011. Oil Price History and Analysis. Available from: http://www.wtrg.com/prices.htm [Accessed 20 April 2014]. 